\title{
Evaluating the cause-of-death information needed for estimating the burden of injury mortality: United States, 2019
}

by Holly Hedegaard, M.D., M.S.P.H., Division of Analysis and Epidemiology; and Margaret Warner, Ph.D., Division of Vital Statistics

\section{Abstract}

Objective-This study evaluated the quality of the causeof-death information on death certificates for injury deaths, by determining the percentage of deaths for which the underlying cause was a nonspecific injury mechanism.

Methods - Injury deaths were identified from 2019 National Vital Statistics System mortality data using underlying-cause-ofdeath (UCOD) codes U01-U03, V01-Y36, Y85-Y87, and Y89. Deaths were categorized by intent and mechanism of injury using the ICD-10 External Cause of Injury Mortality Matrix. The percentage of injury deaths assigned a nonspecific injury mechanism UCOD code was determined for various intent and mechanism categories.

Results-In 2019, 246,041 injury deaths occurred, of which 173,040 were unintentional, 47,511 suicide and intentional self-harm, 19,141 homicide, 5,683 undetermined intent, and 666 resulting from legal intervention and war operations. The percentage of deaths assigned a nonspecific UCOD mechanism code varied from $0.2 \%$ for suicide and intentional self-harm deaths to $10.6 \%$ for injury deaths of undetermined intent. Within an intent-by-mechanism-of-injury category, more specific injury mechanism codes can be assigned if sufficient information is provided on the death certificate. Otherwise, a nonspecific injury mechanism is assigned. What is considered to be specific varies for each injury mechanism. For most unintentional injury mechanism categories, less than $15 \%$ of the deaths received a nonspecific mechanism code. Percentages were higher for unintentional falls $(44.6 \%)$, motor vehicle traffic $(31.1 \%)$, and firearm-related $(75.9 \%)$ deaths. High percentages were also seen for firearm-related suicides $(62.9 \%)$ and firearm-related homicides (89.5\%). The percentage of deaths with a nonspecific injury mechanism UCOD code varied by state.
Conclusions-Death certificate documentation allowed assignment of a general mechanism of injury for the majority of injury deaths in 2019. Improvements in documentation are most needed for deaths involving falls, motor vehicles, and firearms. Study results can help inform medical examiners, coroners, and other death certifiers about the need to improve cause-of-death statements to enhance the usefulness of mortality data for public health.

Keywords: death certification - International Classification of Diseases, 10th Revision • National Vital Statistics System, Mortality

\section{Introduction}

Reliable estimates of the burden of deaths due to injury provide essential information for shaping national health priorities and identifying prevention strategies $(1,2)$. Many estimates rely on data from the National Vital Statistics System, Mortality (NVSS-M) files, a data set that includes information from all death certificates filed in the 50 states and the District of Columbia (3).

In generating NVSS-M, the National Center for Health Statistics (NCHS) uses information from the cause-ofdeath statements in the death certificate literal text to assign underlying- and multiple-cause-of-death codes from the International Classification of Diseases, 10th Revision (ICD-10). ICD-10 is a classification system developed by the World Health Organization (WHO) to facilitate international comparison of mortality statistics (4). The literal text is the written information provided by the medical certifier, often a coroner or medical examiner in the case of an injury death, that describes the cause of death and other factors or circumstances contributing to the death (5). The literal text is captured in three fields of the U.S.

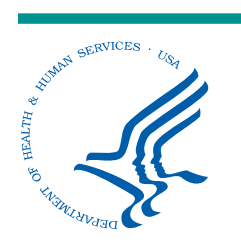

U.S. DEPARTMENT OF HEALTH AND HUMAN SERVICES

Centers for Disease Control and Prevention

National Center for Health Statistics

National Vital Statistics System 
standard death certificate: the causes of death from Part I, the significant conditions contributing to death from Part II, and a description of how the injury occurred (6). NCHS uses the literal text in conjunction with standard practices, coding software, and WHO coding rules to assign the ICD-10 codes for underlying and multiple causes of death $(3,7)$.

The ICD-10 codes for external causes of injury convey information about the intent and mechanism of the injury. Intent of injury describes whether the injury was inflicted purposefully (intentional injury) and, if purposeful, whether the injury was self-inflicted (suicide or self-harm) or inflicted by another person (homicide) (8). Injuries that were not purposefully inflicted are considered unintentional (accidental) injuries. Additional intentof-injury categories include undetermined intent; and legal intervention and war operations. Mechanism of injury describes the source of the energy transfer that resulted in physical or physiological harm to the body. Examples of mechanisms of injury include falls, motor vehicle traffic crashes, burns, poisonings, and drownings (8).

Injury-related ICD-10 codes vary in their level of detail for describing an injury event, from being relatively nonspecific (such as W19, Unspecified fall) to more specific (such as W02, Fall involving ice-skates, skis, roller-skates or skateboards) (4). When a cause-of-death statement in the death certificate literal text provides sufficient detail, a more specific ICD-10 code can be assigned. For example, for fall-related deaths, when sufficient information is provided, specific ICD-10 codes can be used to distinguish falls that occurred on the same level due to slipping, tripping, and stumbling; falls from beds, chairs, and other furniture; falls on or from stairs, steps, ladders, and scaffolding; falls from a building, tree, or cliff; and other types of falls (Technical Notes). For drowning-related deaths, specific ICD-10 codes can be used to distinguish deaths based on where the drowning occurred (such as in a bathtub, swimming pool, or natural body of water). For firearm-related deaths, specific ICD-10 codes can be used to distinguish deaths based on the general type of firearm involved (such as handgun; or rifle, shotgun, or other larger firearms). When the cause-of-death statement lacks sufficient detail, however, a nonspecific ICD-10 code (for example, a code such as W19, Unspecified fall or W74, Unspecified drowning and submersion) is assigned to the death.

This study measured the percentage of injury deaths that received a nonspecific injury mechanism ICD-10 underlyingcause-of-death (UCOD) code, by intent and mechanism of injury. The study was conducted in two stages: 1) for each intent-ofinjury category, the percentage of deaths that did not specify a general injury mechanism in the cause of death was measured, and 2) for each general mechanism-of-injury category, the percentage of deaths that did not receive a more specific ICD-10 injury mechanism code was measured. As described above, what is considered a specific injury mechanism varies by mechanism category. For example, for falls, a specific injury mechanism is one in which specific information is provided on the type of fall; for drowning, a specific mechanism is one in which information is provided on the location of the drowning; for firearm-related deaths, a specific mechanism is one in which information is provided on the general type of firearm involved (handgun or long gun). Because states can vary in their medicolegal death investigation systems and processes, including the person or position responsible for completing the cause of death section of the death certificate (9), state differences were also examined.

Study results can help identify injury topic areas where improvements in cause-of-death statements on death certificates are needed. Improvements in cause-of-death statements can lead to improvements in the quality of the mortality data that are essential for public health surveillance and injury prevention efforts.

\section{Methods}

This study was conducted using 2019 NVSS-M data (10). Injury deaths were identified as those deaths with an ICD-10 UCOD code of U01-U03, V01-Y36, Y85-Y87, or Y89. Deaths were categorized using the ICD-10 External Cause of Injury Mortality Matrix, a standard categorization schema for grouping ICD-10 external cause of injury codes by intent and mechanism of injury (11). Intent-of-injury categories in the ICD-10 External Cause of Injury Mortality Matrix include unintentional, suicide and intentional self-harm, homicide, undetermined intent, and legal intervention and war operations. The mechanism-of-injury categories examined in this study included drowning, fall, fire and flames, hot objects and substances, suffocation, drug poisoning, nondrug poisoning, motor vehicle traffic, and firearm-related.

The proportion (percentage) of injury deaths assigned a nonspecific-injury-mechanism UCOD code was determined for the intent-by-mechanism-of-injury categories that include a nonspecific-injury-mechanism code (generally defined as a code where further information on the mechanism of injury is "unspecified") (Technical Notes). Many of the nonspecificinjury-mechanism UCOD codes used in this analysis were also identified in a recent National Vital Statistics Report on unsuitable underlying causes of death (12).

For most intent-by-mechanism-of-injury categories, a single code identified the nonspecific-injury-mechanism (Technical Notes). However, for drug and nondrug poisonings, a combination of underlying and multiple cause codes was needed to identify a death for which a specific drug or substance was not identified. For unintentional drug poisoning deaths (deaths with UCOD codes X40-X44) and for suicide drug poisoning deaths (deaths with UCOD codes X60-X64), the mechanism of injury was considered nonspecific (that is, a specific drug was not identified) if the underlying cause code was X44 (in the case of unintentional drug poisoning) or X64 (in the case of suicide by drug poisoning), and the only drug-related multiple cause code was T50.9, Other and unspecified drugs, medicaments and biological substances (Technical Notes). For unintentional nondrug poisoning deaths (deaths with UCOD codes X45-X49) and for suicide nondrug poisoning deaths (deaths with UCOD codes X65-X69), the mechanism of injury was considered nonspecific (that is, a specific substance was not identified) if the underlying cause was X49 (in the case of unintentional nondrug poisoning) or X69 (in the case of suicide by nondrug poisoning), and the only nondrug-related multiple cause code was T65.9, Toxic effect of unspecified substance (Technical Notes). 
Some of the nonspecific injury mechanism UCOD codes capture "other and unspecified" mechanisms (for example, X19, Contact with other and unspecified heat and hot substances; W34, Discharge from other and unspecified firearms; X74, Intentional self-harm by other and unspecified firearm discharge; and X95, Assault by other and unspecified firearm discharge) (Technical Notes). For deaths assigned these codes, the literal text on a sample of cases was reviewed to determine the frequency with which an "other" mechanism was identified. This review indicated that for the majority of deaths assigned one of these "other and unspecified" codes, the details of the mechanism were unspecified (that is, an "other" mechanism was not identified).

The percentage of deaths assigned a nonspecific injury mechanism UCOD was examined by the decedent's state of residence for all unintentional injury deaths, all homicides, and for those intent-by-mechanism-of-injury categories that had more than 500 deaths and for which more than $15 \%$ of the deaths were assigned a nonspecific injury mechanism UCOD code (that is, unintentional fall deaths, unintentional motor vehicle traffic deaths, firearm-related suicides, and firearm-related homicides).

\section{Results}

\section{Deaths by intent of injury}

In 2019, 246,041 injury deaths occurred in the United States, of which 173,040 were categorized as unintentional (accidental), 47,511 as suicide and intentional self-harm, 19,141 as homicide, 5,683 as undetermined intent, and 666 as resulting from legal intervention or war operations. Table A shows the percentage of deaths assigned a nonspecific injury mechanism UCOD code for each intent-of-injury category. The percentage varied from $0.2 \%$ for suicide and intentional self-harm deaths to $10.6 \%$ for injury deaths of undetermined intent.
Figures 1 and 2 and Tables 1 and 2 show the percentage of deaths with a UCOD code indicating a nonspecific mechanism for unintentional injury deaths and homicides, respectively, by state. Due to small numbers, results by state are not shown for deaths from suicide and intentional self-harm, injury deaths of undetermined intent, and deaths resulting from legal intervention and war operations. Nationally, $3.7 \%$ of unintentional injury deaths had an ICD-10 UCOD code for nonspecific injury mechanism. Percentages by state ranged from $0.8 \%$ (South Dakota) to $8.3 \%$ (Alabama) (Figure 1, Table 1). For homicides, $6.5 \%$ nationally had a nonspecific mechanism code, with percentages by state ranging from $2.2 \%$ (New Mexico) to $56.5 \%$ (Maine) (Figure 2, Table 2).

\section{Specificity of mechanism for unintentional injury deaths}

As described in the Introduction, ICD-10 codes provide different levels of specificity within a mechanism-of-injury category. Table B shows the percentage of deaths assigned a nonspecific injury mechanism UCOD code for various intentby-mechanism-of-injury categories. For example, of the 3,692 unintentional drowning deaths identified by ICD-10 UCOD codes W65-W74, $11.1 \%$ received a UCOD code of W74, Unspecified drowning and submersion (Table B). For most injury mechanism categories, the percentage of deaths receiving a nonspecific-injury-mechanism code was less than $15 \%$. For three unintentional injury categories (fall, motor vehicle traffic, and firearm-related), the percentage of deaths assigned a nonspecific-injury-mechanism code was greater than $15 \%(44.6 \%, 31.1 \%$, and $75.9 \%$, respectively). The definition of "nonspecific" varies for each mechanism. For falls, "nonspecific" indicates that information on the details of the fall (for example, on the same level or from one level to another) were not identified; for motor vehicle traffic, that information on the role of the decedent (for example, vehicle occupant or

Table A. Percentage of deaths with a nonspecific-injury-mechanism underlying cause, by intent of injury: United States, 2019

\begin{tabular}{|c|c|c|c|c|}
\hline $\begin{array}{c}\text { Intent of injury and International } \\
\text { Classification of Diseases, 10th Revision } \\
\text { codes for intent }\end{array}$ & $\begin{array}{l}\text { Total number } \\
\text { of deaths }\end{array}$ & $\begin{array}{c}\text { Code }(\mathrm{s}) \text { indicating a } \\
\text { nonspecific-injury-mechanism } \\
\text { underlying cause }\end{array}$ & $\begin{array}{l}\text { Number of deaths } \\
\text { with a nonspecific- } \\
\text { injury-mechanism } \\
\text { underlying cause }\end{array}$ & $\begin{array}{l}\text { Percent of deaths } \\
\text { with a nonspecific- } \\
\text { injury-mechanism } \\
\text { underlying cause }\end{array}$ \\
\hline Unintentional . ................... V01-X59, Y85-Y86 & 173,040 & $\begin{array}{l}\text { X59.0, Exposure to unspecified factor } \\
\text { causing fracture; X59.9, Exposure to } \\
\text { unspecified factor causing other and } \\
\text { unspecified injury }\end{array}$ & 6,369 & 3.7 \\
\hline Suicide and intentional self-harm. ...... U03, X60-X84, Y87.0 & 47,511 & $\begin{array}{l}\text { X84, Intentional self-harm by } \\
\text { unspecified means }\end{array}$ & 80 & 0.2 \\
\hline Homicide . . . . . . . . . . . . . . U01-U02, X85-Y09, Y87.1 & 19,141 & Y09, Assault by unspecified means & 1,247 & 6.5 \\
\hline 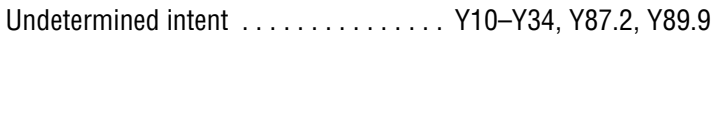 & 5,683 & $\begin{array}{l}\text { Y34, Unspecified event; Y89.9, } \\
\text { Sequelae of unspecified external } \\
\text { cause }\end{array}$ & 600 & 10.6 \\
\hline Legal intervention or war operations . ....Y35-Y36, Y89 (.0-.1) & 666 & $\begin{array}{l}\text { Y35.7, Legal intervention, means } \\
\text { unspecified; Y36.9, War operations, } \\
\text { unspecified }\end{array}$ & Suppressed & Not calculated \\
\hline
\end{tabular}

NOTES: Injury deaths are identified using the International Classification of Diseases, 10th Revision underlying-cause-of-death codes U01-U03, V01-Y36, Y85-Y87, and Y89. Deaths were categorized by intent and mechanism of death using the Injury Mortality Matrix, available from: https://www.cdc.gov/nchs/injury/injury_tools.htm. Cells with fewer than 10 deaths are suppressed

SOURCE: National Vital Statistics System, Mortality (NVSS-M), 2019. 
Figure 1. Percentage of unintentional injury deaths with X59, Exposure to unspecified factor causing other or unspecified injury, as the underlying cause of death, by state: 2019

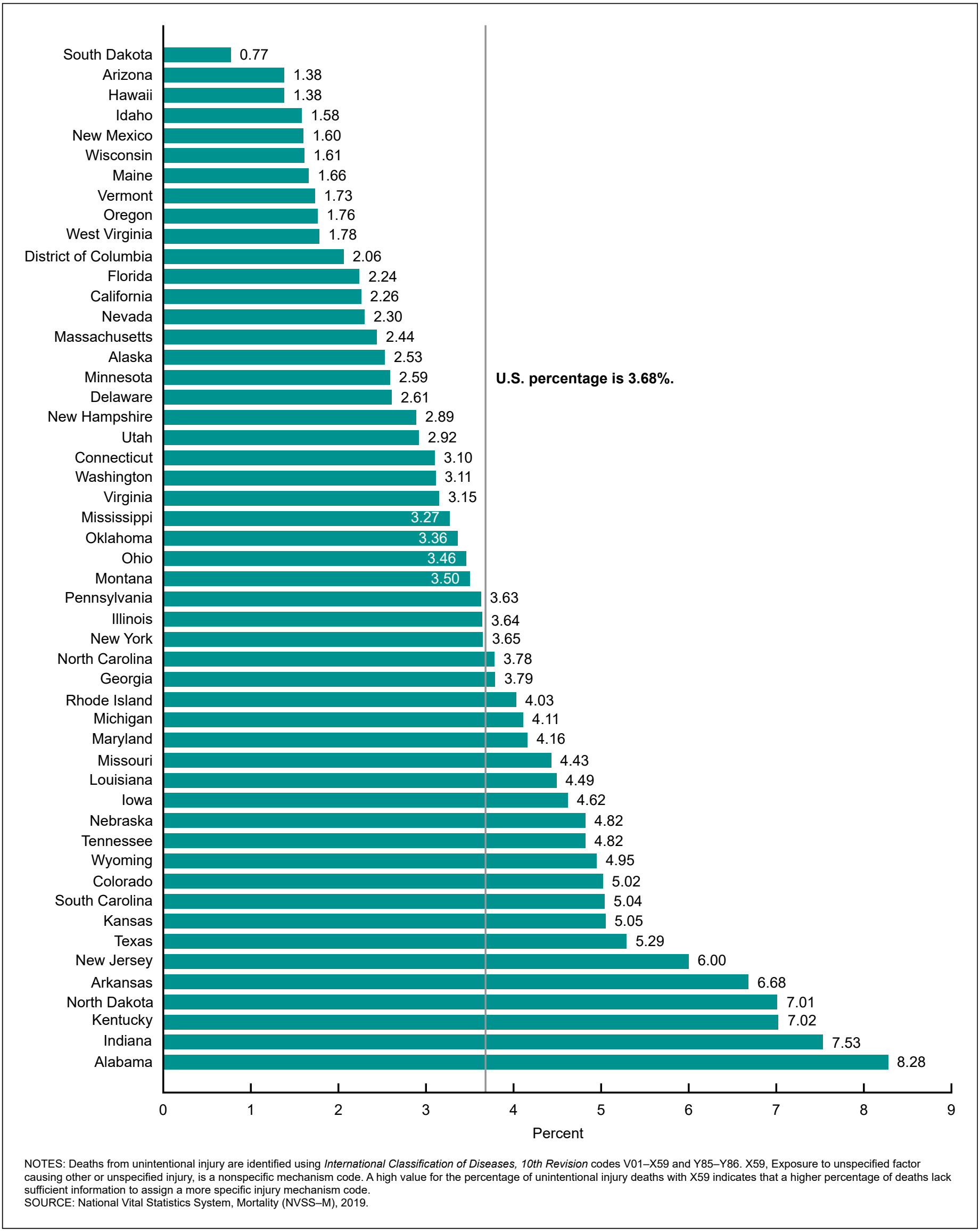


Figure 2. Percentage of homicide deaths with Y09, Assault by unspecified means, as the underlying cause of death, by state: 2019

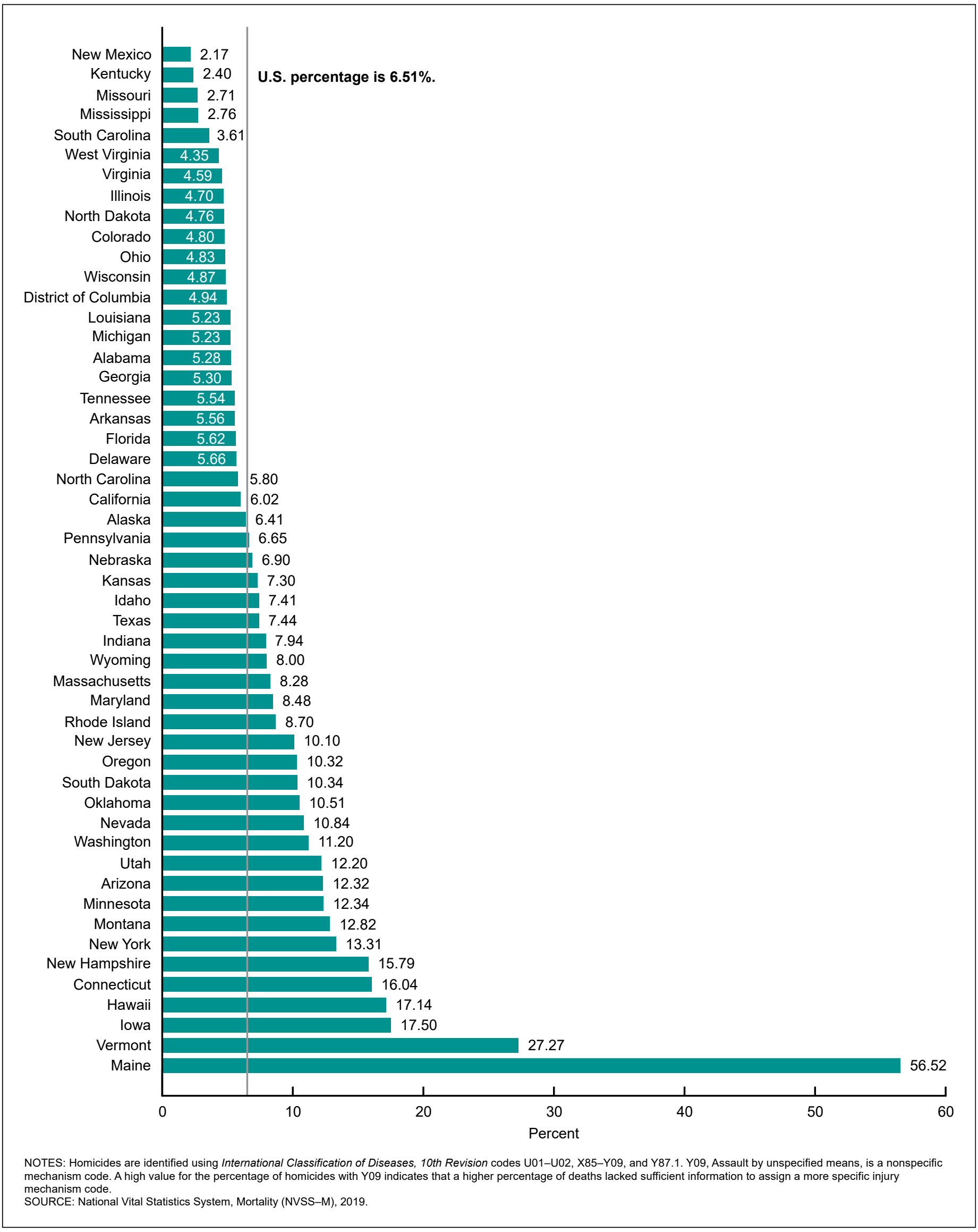




\begin{tabular}{|c|c|c|c|c|}
\hline $\begin{array}{l}\text { Intent and mechanism of injury and } \\
\text { International Classification of Diseases, 10th Revision } \\
\text { codes for intent and mechanism }\end{array}$ & $\begin{array}{l}\text { Total number } \\
\text { of deaths }\end{array}$ & $\begin{array}{c}\text { Code(s) indicating a } \\
\text { nonspecific-injury-mechanism } \\
\text { underlying cause }\end{array}$ & $\begin{array}{l}\text { Number of deaths with } \\
\text { a nonspecific-injury- } \\
\text { mechanism } \\
\text { underlying cause }\end{array}$ & $\begin{array}{l}\text { Percent of deaths with } \\
\text { a nonspecific-injury- } \\
\text { mechanism } \\
\text { underlying cause }\end{array}$ \\
\hline \multicolumn{5}{|l|}{ Unintentional } \\
\hline$\ldots \ldots W 65-W 74$ & 3,692 & W74, Unspecified drowning and submersion & 408 & 11.1 \\
\hline 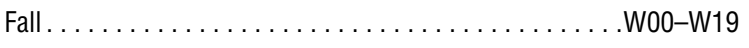 & 39,443 & W19, Unspecified fall & 17,576 & 44.6 \\
\hline$\ldots \ldots \ldots \ldots \ldots \ldots \ldots \times \mathrm{X}_{00} \mathrm{X} 09$ & 2,692 & X09, Exposure to unspecified smoke, fire and flames & 136 & 5.1 \\
\hline Hot object and substance. ......................... 10 & 66 & $\begin{array}{l}\text { X19, Contact with other and unspecified heat and hot } \\
\text { substances }\end{array}$ & Suppressed & Not calculated \\
\hline$\ldots \ldots \ldots \ldots \ldots \ldots \ldots$ W32-W34 & 486 & W34, Discharge from other and unspecified firearms & 369 & 75.9 \\
\hline Suffocation. ................................W754 & 7,076 & W84, Unspecified threat to breathing & 459 & 6.5 \\
\hline Drug poisoning $\ldots \ldots \ldots \ldots \ldots \ldots \ldots \ldots \ldots \ldots \ldots \ldots \ldots \ldots \ldots \ldots \ldots \ldots$ & 62,172 & $\begin{array}{l}\text { X44, Accidental poisoning by and exposure to other and } \\
\text { unspecified drugs, medicaments and biological substances } \\
\text { and the only drug-related multiple cause code is T50.9, } \\
\text { Other and unspecified drugs, medicaments and biological } \\
\text { substances }\end{array}$ & 3,574 & 5.7 \\
\hline Nondrug poisoning . & 3,601 & $\begin{array}{l}\text { X49, Accidental poisoning by and exposure to other and } \\
\text { unspecified chemicals and noxious substances and the only } \\
\text { nondrug poisoning-related multiple cause code is T65.9, } \\
\text { Toxic effect of unspecified substance }\end{array}$ & 180 & 5.0 \\
\hline 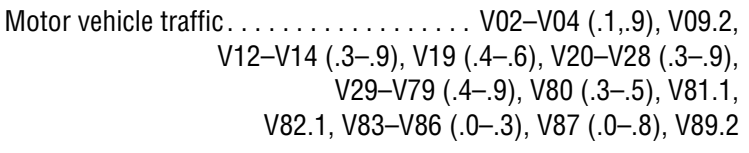 & 37,595 & $\begin{array}{l}\text { V89.2, Person injured in unspecified motor-vehicle accident, } \\
\text { traffic }\end{array}$ & 11,704 & 31.1 \\
\hline \multicolumn{5}{|l|}{ Suicide and intentional self-harm } \\
\hline Firearm-related. .............................. & 23,941 & $\begin{array}{l}\text { X74, Intentional self-harm by other and unspecified firearm } \\
\text { discharge }\end{array}$ & 15,060 & 62.9 \\
\hline Drug poisoning . & 4,777 & $\begin{array}{l}\text { X64, Intentional self-poisoning by and exposure to other and } \\
\text { unspecified drugs, medicaments and biological substances } \\
\text { and the only drug-related multiple cause code is T50.9, } \\
\text { Other and unspecified drugs, medicaments and biological } \\
\text { substances }\end{array}$ & 440 & 9.2 \\
\hline Nondrug poisoning & 1,348 & $\begin{array}{l}\text { X69, Intentional self-poisoning by and exposure to other and } \\
\text { unspecified chemicals and noxious substances and the only } \\
\text { nondrug poisoning-related multiple cause code is T65.9, } \\
\text { Toxic effect of unspecified substance }\end{array}$ & 34 & 2.5 \\
\hline \multicolumn{5}{|l|}{ Homicide } \\
\hline Firearm-related. .................... U01.4, X93-X95 & 14,414 & X95, Assault by other and unspecified firearm discharge & 12,906 & 89.5 \\
\hline
\end{tabular}

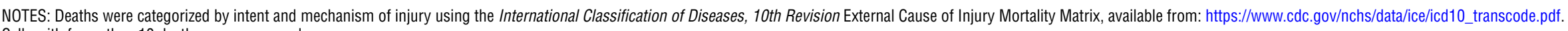
Cells with fewer than 10 deaths are suppressed.

SOURCE: National Vital Statistics System, Mortality (NVSS-M), 2019. 
motorcyclist) and types of vehicles involved in the crash were not identified; for firearm-related, that the type of firearm (handgun or long gun) was not identified. Figures 3 and 4 and Tables 3 and 4 show the percentage of deaths with a nonspecific-injurymechanism code for unintentional fall deaths and unintentional motor vehicle traffic deaths, respectively, by state. Results by state for unintentional firearm-related deaths are not shown due to small numbers. Nationally, $44.6 \%$ of unintentional fall deaths had a nonspecific-injury-mechanism code, with percentages by state ranging from $6.0 \%$ (West Virginia) to $95.2 \%$ (Oklahoma) (Figure 3, Table 3). For unintentional motor vehicle traffic deaths, $31.1 \%$ of deaths nationally had a nonspecific mechanism code, with state percentages ranging from $4.8 \%$ (Florida) to $53.7 \%$ (Tennessee) (Figure 4, Table 4).

\section{Specificity of mechanism for suicide and intentional self-harm deaths}

The percentage of deaths assigned a nonspecific injury mechanism UCOD code for suicide and intentional self-harm deaths is shown in Table $B$. The percentage varied by mechanism: $2.5 \%$ for suicides by nondrug poisoning, $9.2 \%$ for suicides by drug poisoning (overdose), and $62.9 \%$ for firearm-related suicides. The definition of nonspecific varies for each mechanism. For nondrug poisoning, nonspecific indicates that the specific substance(s) involved were not identified; for drug poisoning, that the specific drug(s) involved were not identified; for firearmrelated, that the type of firearm (handgun or long gun) was not identified. Figure 5 and Table 5 show the percentage of deaths with a nonspecific mechanism code for firearm-related suicide deaths by state. The percentage of firearm-related suicides with a nonspecific mechanism code ranged from $2.7 \%$ (Idaho) to $100 \%$ (District of Columbia).

\section{Specificity of mechanism for homicide deaths}

The percentage of deaths assigned a nonspecific injury mechanism UCOD code for firearm-related homicides is shown in Table B. The majority (89.5\%) of firearm-related homicides were assigned a nonspecific mechanism code: X95, Assault by other and unspecified firearm discharge. Figure 6 and Table 6 show the percentage of deaths with a nonspecific mechanism code for firearm-related homicides by state. The percentage of firearm-related homicides with a nonspecific mechanism code ranged from $16.7 \%$ (Idaho) to $100 \%$ (Delaware, Hawaii, and Rhode Island).

\section{Discussion}

Overall, information provided in cause-of-death statements in the literal text of death certificates allowed assignment of a general mechanism of injury for the majority of injury deaths in 2019. However, the level of specificity in the injury mechanism UCOD code varied by intent and mechanism of injury. The percentage of deaths with a nonspecific code for an injury mechanism varied by intent from $0.2 \%$ for suicide and intentional self-harm deaths to $10.6 \%$ for injury deaths of undetermined intent. Differences were also observed for various intent-by-mechanism-of-injury categories and by state. Three unintentional injury categories (fall, motor vehicle traffic, and firearm-related) had high percentages of deaths assigned a nonspecific mechanism code $(44.6 \%, 31.1 \%$, and $75.9 \%$, respectively). Higher percentages were also seen for firearmrelated suicides (62.9\%) and firearm-related homicides (89.5\%).

The differences by state have several implications. First, the wide range by state in the percentage of injury deaths with a nonspecific injury mechanism UCOD code make it difficult to conduct state-to-state comparisons for certain intent-bymechanism-of-injury subcategories, particularly for fall, motor vehicle traffic, and firearm-related deaths. State rates for specific mechanism-of-injury subcategories might appear artificially low if a high percentage of deaths are assigned a nonspecific mechanism code. State differences in specificity should be considered when comparing rates of intent-by-mechanismof-injury subcategories by state. Second, understanding the practices and protocols used in states with low percentages of nonspecific mechanism codes might help inform strategies for improving cause-of-death statements and death certificate documentation in other states and jurisdictions.

Improvements in death certificate documentation, particularly providing specific details in the cause-of-death statements, could help lower the percentage of deaths assigned a nonspecific injury mechanism UCOD code. For example, for fall deaths, details such as whether the fall occurred on the same level or from one level to another (for example, from bed, chairs, or other furniture; from stairs, steps, or ladders; or from a building, scaffolding, tree, or cliff) would provide the information needed by NCHS to assign a more specific mechanism code. For motor vehicle traffic deaths, key information needed in the cause-of-death statement includes the role of the decedent (vehicle occupant, motorcyclist, bicyclist, pedestrian, or other) as well as the type of event (such as collision or roll-over) and the type of vehicles involved (such as car, truck, motorcycle, van, bus, or 3-wheeled vehicle) $(5,13)$. The terms "MVA," "MVC," and "MCA" (motor vehicle accident, motor vehicle crash, and motorcycle accident, respectively) often used in cause-of-death statements do not provide sufficient detail for assignment of a specific injury mechanism code, which is more useful for public health purposes. In these instances, V89.2, Person injured in unspecified motor-vehicle accident, in traffic is often assigned. Nearly one-third (31.1\%) of motor vehicle traffic deaths in 2019 received this code. This lack of specificity reduces the usefulness of vital statistics data for monitoring and informing public health efforts in injury prevention.

The injury mechanism category with the highest percentage of deaths assigned a nonspecific injury mechanism UCOD code is firearm-related deaths $(75.9 \%$ of unintentional firearm-related deaths, $62.9 \%$ of firearm-related suicides and intentional selfharm deaths, and $89.5 \%$ of firearm-related homicides). ICD-10 includes unique codes that can distinguish between deaths involving handguns (W32, X72, and X93) and deaths involving long guns, such as rifles, shotguns, and other larger guns (W33, $\mathrm{X73}$, and X94). For many deaths, the firearm involved might not be determined during the death investigation. However, when the 
Figure 3. Percentage of unintentional fall deaths with W19, Unspecified fall, as the underlying cause of death, by state: 2019

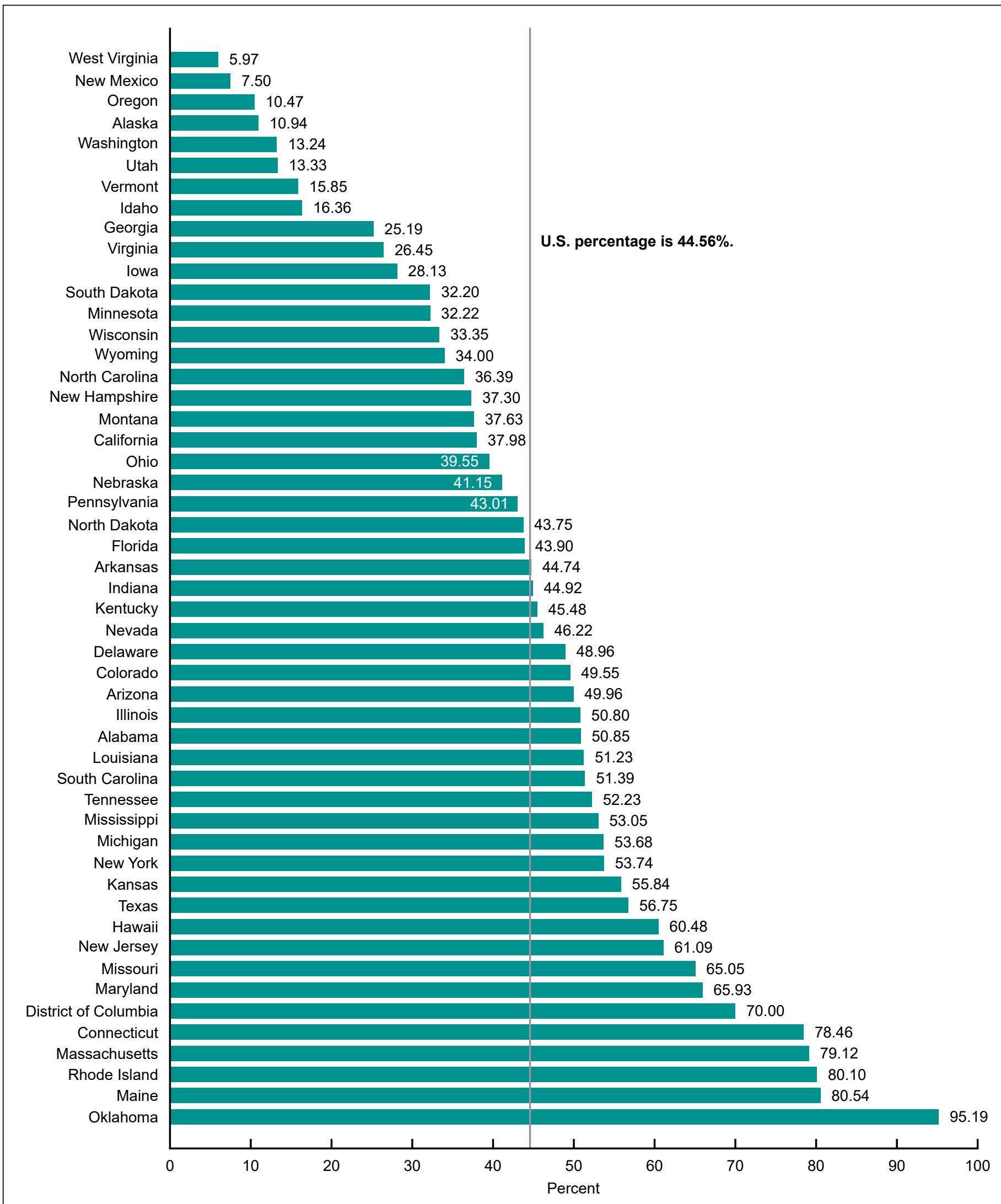

NOTES: Deaths from unintentional falls are identified using International Classification of Diseases, 10th Revision codes W00-W19. W19, Unspecified fall, is a less specific mechanism code. A high value for the percentage of unintentional fall deaths with W19 indicates that a higher percentage of deaths lacked sufficient information to assign a more specific fall code. SOURCE: National Vital Statistics System, Mortality (NVSS-M), 2019. 
Figure 4. Percentage of unintentional motor vehicle traffic-related deaths with V89.2, Person injured in unspecified motor-vehicle accident, traffic, as the underlying cause of death, by state: 2019

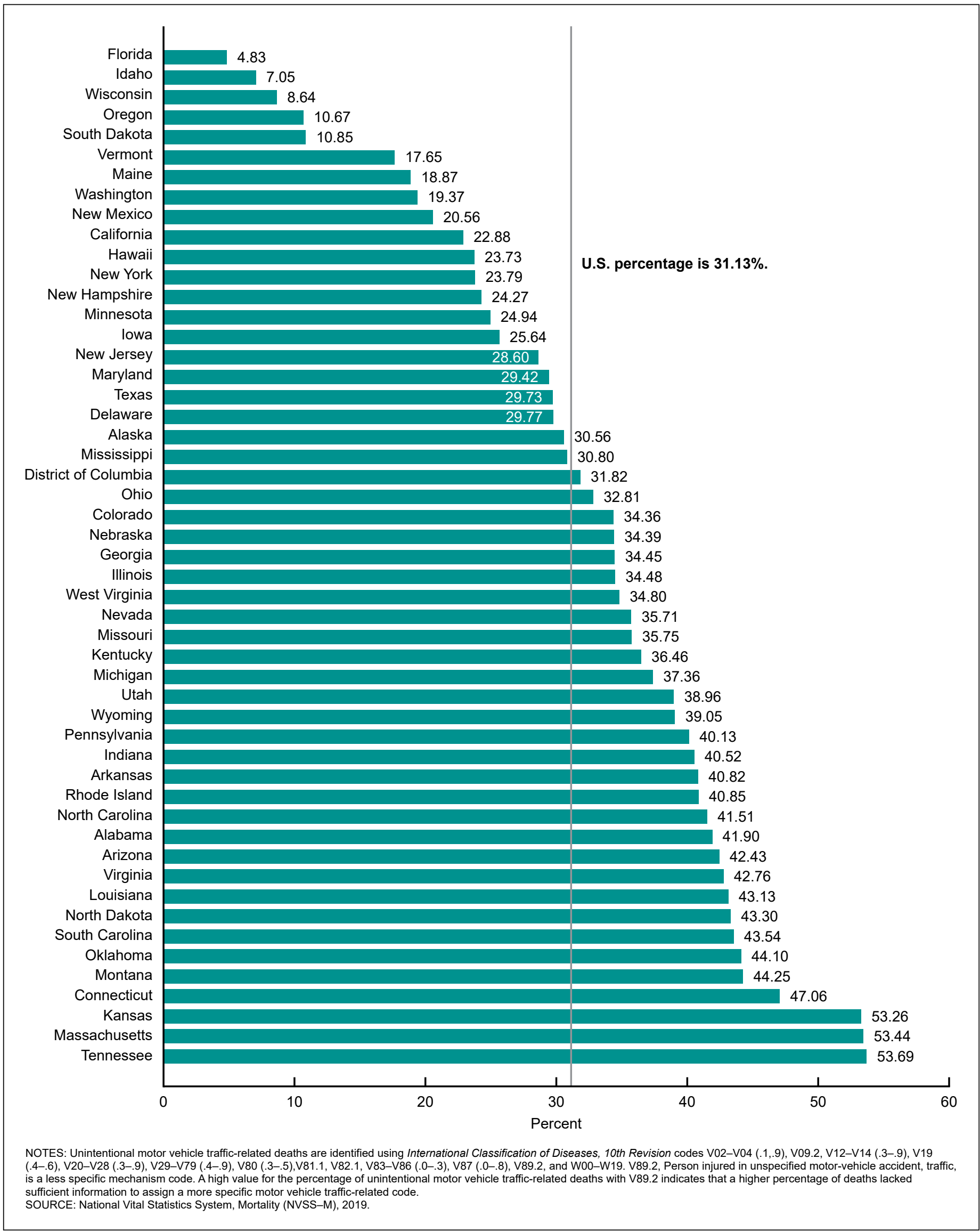


Figure 5. Percentage of firearm-related suicide and intentional self-harm deaths with $\mathrm{X74}$, Intentional self-harm by other and unspecified firearm discharge, as the underlying cause of death, by state: 2019

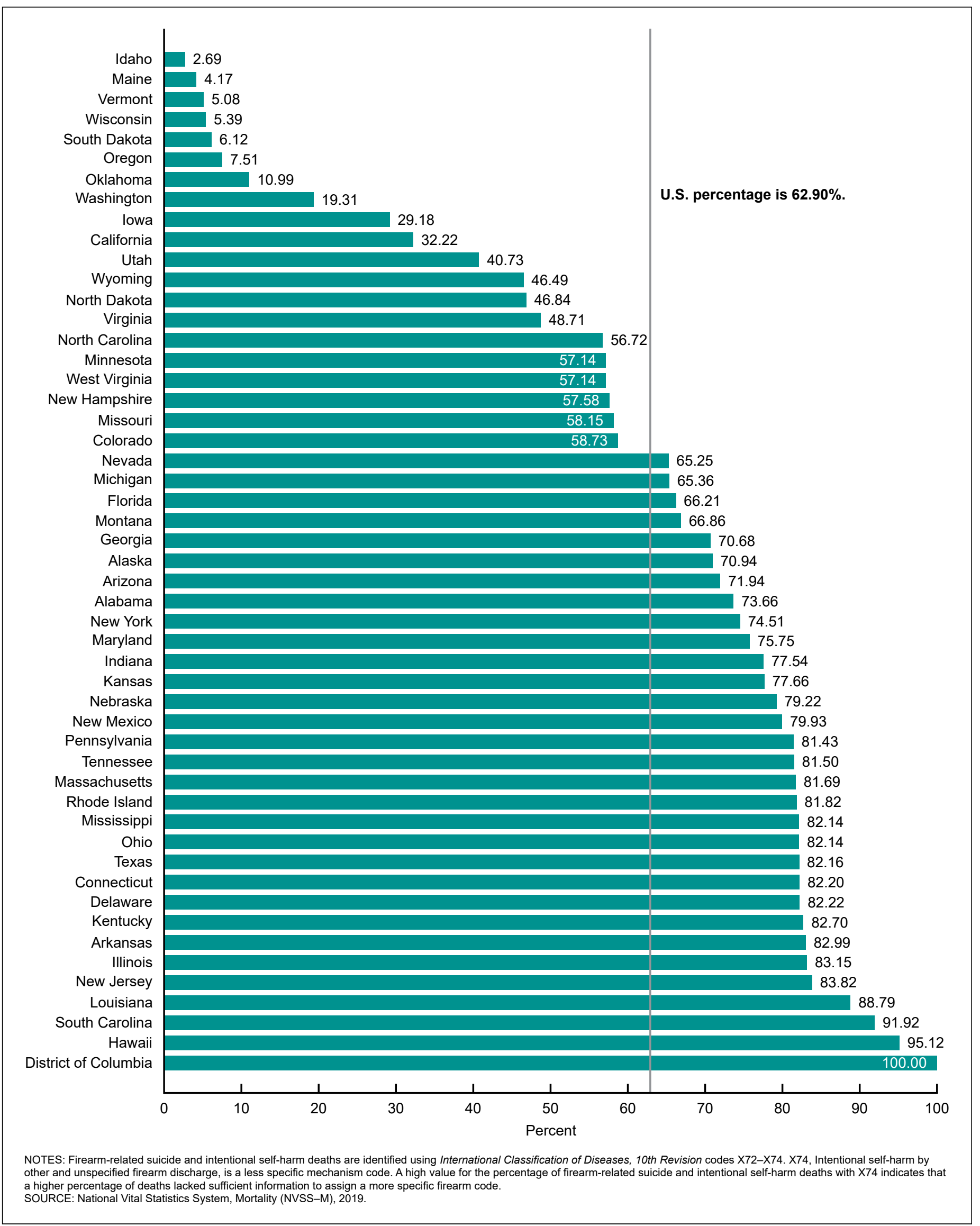


Figure 6. Percentage of firearm-related homicides with X95, Assault by other and unspecified firearm discharge, as the underlying cause of death, by state: 2019

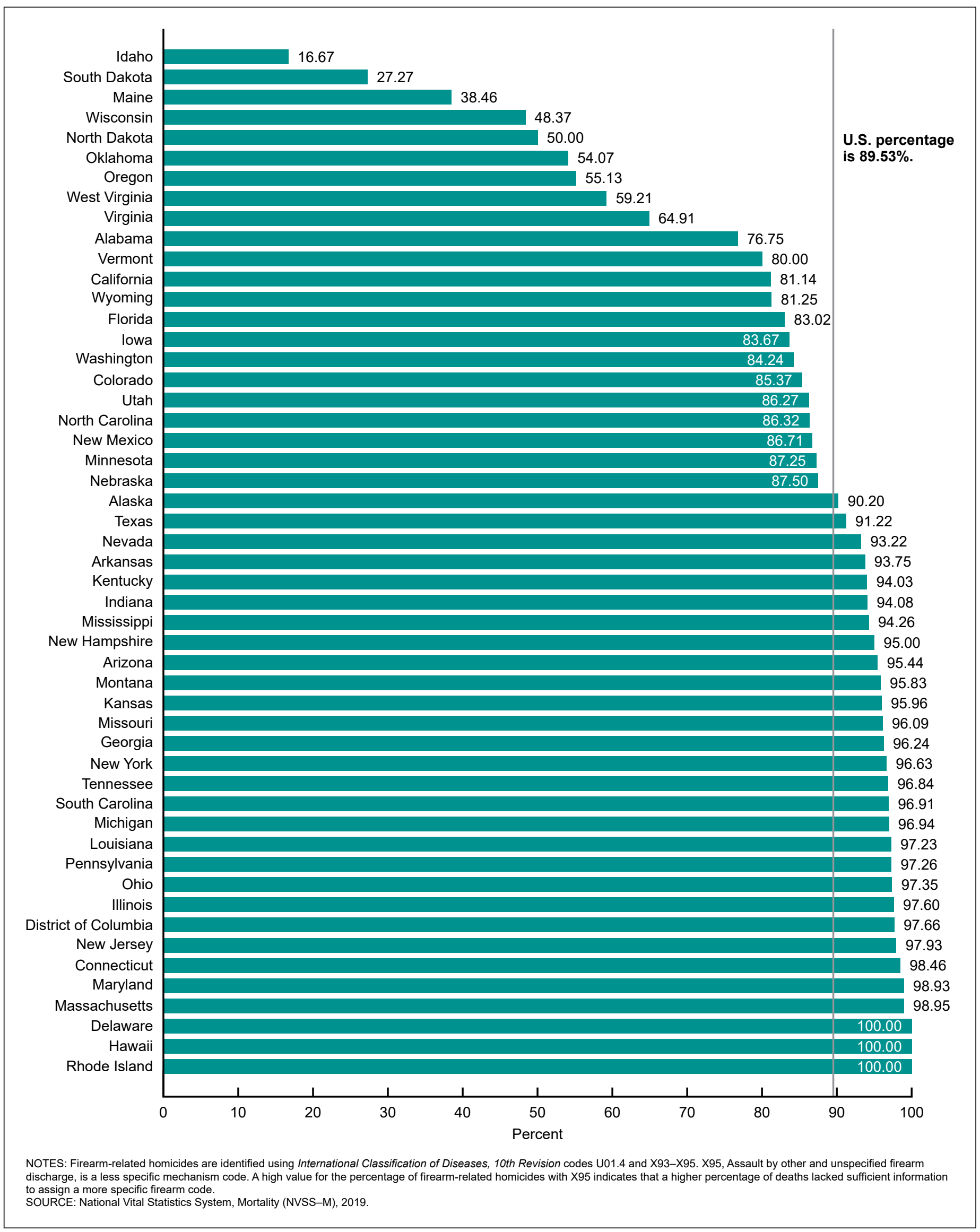


general type of firearm (such as handgun, rifle, shotgun, or long gun) is known, documentation of this information on the death certificate would allow assignment of a more specific ICD-10 code. Other details, such as the make and model of the firearm, are not needed or required $(5,13)$. The term "GSW" for gunshot wound, often found in cause-of-death statements for firearmrelated deaths, is not sufficient for assigning a more specific code for the type of firearm involved.

Recent efforts to improve cause-of-death statements on death certificates for other causes of death have resulted in substantial improvements in the specificity of information available in mortality data. For example, the quality of mortality data on the drugs involved in overdose deaths improved substantially after examining completeness in drug reporting by state, identifying possible solutions, and working with state and local medical examiners and coroners to implement improvements (14-16). As a result of multiple collaborative efforts, the percentage of overdose deaths that identified at least one specific drug on the death certificate increased from $45 \%$ of deaths in 2013 to 80\% in 2017 (17). In 2019, the percentage increased to $94 \%$ (18). NCHS has developed a new series of Vital Statistics Reference Guides to provide instructions and guidance to medical certifiers on completing the death certificate for specific causes of death $(19,20)$. A similar multipronged collaborative approach, including the creation of reference guides, might be useful for improving documentation and causeof-death statements for other injury topics.

\section{Conclusions}

Improvements in the cause-of-death statements on the death certificate can result in more specific coding of the mechanism and intent-of-injury deaths. Efforts to improve death certificate documentation and increase the specificity of causeof-death coding, particularly for fall, motor vehicle, and firearmrelated deaths, will enhance the usefulness of mortality data for understanding the burden of injury death in the United States and for informing public health prevention efforts.

\section{References}

1. Bhalla K, Harrison JE, Shahraz S, Fingerhut LA. Availability and quality of cause-of-death data for estimating the global burden of injuries. Bull World Health Organ 88(11):831838C. 2010. D0I: https://doi.org/10.2471/BLT.09.068809.

2. Mathers CD, Fat DM, Inoue M, Rao C, Lopez AD. Counting the dead and what they died from: An assessment of the global status of cause of death data. Bull World Health Organ 83(3):171-7. 2005.

3. Heron M. Deaths: Leading causes for 2018. National Vital Statistics Reports; vol 70 no 4. Hyattsville, MD: National Center for Health Statistics. 2021. DOI: https://doi.org/ 10.15620/cdc:104186.

4. World Health Organization. International statistical classification of diseases and related health problems, 10th revision (ICD-10). 2008 ed. Geneva, Switzerland. 2009.
5. National Center for Health Statistics. Medical examiners' and coroners' handbook on death registration and fetal death reporting. Hyattsville, MD: National Center for Health Statistics. 2003. Available from: https://www.cdc.gov/nchs/ data/misc/hb_me.pdf.

6. National Center for Health Statistics. 2003 revision of the U.S. Standard Certificate of Death. Available from: https:// www.cdc.gov/nchs/data/dvs/death11-03final-acc.pdf.

7. Anderson RN. Chapter 22: Coding and classifying causes of death: Trends and international differences. In: Rogers RG, Crimmins EM, editors. International handbook of adult mortality. International handbooks of population, Volume 2. Heidelberg, Germany: Springer, 467-89. DOI: 10.1007/97890-481-9996-9_22. 2011.

8. Bergen $G$, Chen LH, Warner M, Fingerhut LA. Injury in the United States: 2007 Chartbook. Hyattsville, MD: National Center for Health Statistics. 2008. Available from: https:// www.cdc.gov/nchs/data/misc/injury2007.pdf.

9. Centers for Disease Control and Prevention Public Health Law Program. Coroner/medical examiner laws, by state. Available from: https://www.cdc.gov/phlp/publications/ topic/coroner.html.

10. National Center for Health Statistics. Public-use data files: Mortality multiple cause files. 2019. Available from: https://www.cdc.gov/nchs/data_access/vitalstatsonline. htm\#Mortality_Multiple.

11. National Center for Health Statistics. ICD framework: External cause of injury mortality matrix. Available from: https://www.cdc.gov/nchs/injury/injury_tools.htm.

12. Flagg LA, Anderson RN. Unsuitable underlying causes of death for assessing the quality of cause-of-death reporting. National Vital Statistics Reports; vol 69 no 14. Hyattsville, MD: National Center for Health Statistics. 2021. Available from: https://www.cdc.gov/nchs/data/nvsr/nvsr69/nvsr6914-508.pdf.

13. National Center for Health Statistics. Instructions for completing the cause-of-death section of the death certificate for injury and poisoning. 2004. Available from: https://www.cdc.gov/nchs/data/dvs/red_form.pdf.

14. Davis GG, National Association of Medical Examiners and American College of Medical Toxicology Expert Panel on Evaluating and Reporting Opioid Deaths. National Association of Medical Examiners position paper: Recommendations for the investigation, diagnosis, and certification of deaths related to opioid drugs. Acad Forensic Pathol 3(1):77-83. 2013.

15. Council of State and Territorial Epidemiologists. Recommendations and lessons learned for improved reporting of drug overdose deaths on death certificates. 2016. Available from: https://cdn.ymaws.com/www.cste. org/resource/resmgr/PDFs/PDFs2/4_25_2016_final-drug_ overdos.pdf. 
16. Association of State and Territorial Health Officials. Improving drug specificity and completeness on death certificates for drug overdose deaths: Opportunities and challenges for states. 2018. Available from: http://www. astho.org/Rx/Improving-Drug-Spec-and-Comp-on-DeathCerts-for-Overdose-Deaths-Meeting-Report/.

17. Warner $\mathrm{M}$, Hedegaard $\mathrm{H}$. Identifying opioid overdose deaths using vital statistics data. Am J Public Health 108(12):15879. 2018. Available from: https://ajph.aphapublications.org/ doi/10.2105/AJPH.2018.304781.

18. Hedegaard H, Miniño AM, Warner M. Drug overdose deaths in the United States, 1999-2019. NCHS Data Brief, no 394. Hyattsville, MD: National Center for Health Statistics. 2020. Available from: https://www.cdc.gov/nchs/data/databriefs/ db394-H.pdf.

19. National Center for Health Statistics. A reference guide for certification of deaths in the event of a natural, humaninduced, or chemical/radiological disaster. Hyattsville, MD. 2017. Available from: https://www.cdc.gov/nchs/data/nvss/ vsrg/vsrg01.pdf.

20. National Center for Health Statistics. A reference guide for completing the death certificate for drug toxicity deaths. Hyattsville, MD. 2019. Available from: https://www.cdc.gov/ nchs/data/nvss/vsrg/vsrg02-508.pdf.

\section{List of Detailed Tables}

1. Percentage of unintentional injury deaths with X59, Exposure to unspecified factor causing other or unspecified injury, as the underlying cause of death, by state: 2019 . . .

2. Percentage of homicide deaths with Y09, Assault by unspecified means, as the underlying cause of death, by state: $2019 \ldots \ldots \ldots \ldots \ldots \ldots \ldots \ldots \ldots \ldots \ldots$.

3. Percentage of unintentional fall deaths with W19, Unspecified fall, as the underlying cause of death, by state: $2019 \ldots \ldots \ldots \ldots \ldots \ldots \ldots \ldots \ldots \ldots \ldots$

4. Percentage of unintentional motor vehicle traffic-related deaths with V89.2, Person injured in unspecified motorvehicle accident, traffic, as the underlying cause of death, by state: $2019 \ldots \ldots \ldots \ldots \ldots \ldots \ldots \ldots \ldots \ldots \ldots \ldots$

5. Percentage of firearm-related suicide and intentional selfharm deaths with $\mathrm{X74}$, Intentional self-harm by other and unspecified firearm discharge, as the underlying cause of death, by state: $2019 \ldots \ldots \ldots \ldots \ldots \ldots \ldots \ldots \ldots$

6. Percentage of firearm-related homicides with X95, Assault by other and unspecified firearm discharge, as the underlying cause of death, by state: $2019 \ldots \ldots \ldots \ldots$. . . 
Table 1. Percentage of unintentional injury deaths with X59, Exposure to unspecified factor causing other or unspecified injury, as the underlying cause of death, by state: 2019

\begin{tabular}{|c|c|c|c|}
\hline Area & $\begin{array}{l}\text { All unintentional } \\
\text { injury deaths }\end{array}$ & $\begin{array}{l}\text { Deaths with X59 as the } \\
\text { underlying cause }\end{array}$ & $\begin{array}{l}\text { Percent of unintentional } \\
\text { injury deaths with X59 as the } \\
\text { underlying cause }\end{array}$ \\
\hline Alabama.. & 2,755 & 228 & 8.28 \\
\hline Alaska ... & 434 & 11 & 2.53 \\
\hline Arizona. . & 4,558 & 63 & 1.38 \\
\hline Arkansas & 1,527 & 102 & 6.68 \\
\hline California . & 15,116 & 342 & 2.26 \\
\hline Colorado. & 3,085 & 155 & 5.02 \\
\hline Connecticut & 2,197 & 68 & 3.10 \\
\hline Delaware . . & 728 & 19 & 2.61 \\
\hline District of Columbia. . & 437 & 9 & 2.06 \\
\hline$\ldots \ldots \ldots \ldots \ldots \ldots \ldots$ & 13,348 & 299 & 2.24 \\
\hline Georgia & 4,563 & 173 & 3.79 \\
\hline Hawaii . . & 651 & 9 & 1.38 \\
\hline Idaho ... & 948 & 15 & 1.58 \\
\hline Illinois & 6,095 & 222 & 3.64 \\
\hline Indiana. . & 3,876 & 292 & 7.53 \\
\hline lowa.... & 1,538 & 71 & 4.62 \\
\hline Kansas. & 1,524 & 77 & 5.05 \\
\hline Kentucky. & 3,121 & 219 & 7.02 \\
\hline Louisiana . . . . . . . . . . . . . . . . . . . . & 2,916 & 131 & 4.49 \\
\hline 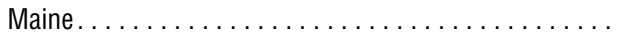 & 1,027 & 17 & 1.66 \\
\hline Maryland . & 2,425 & 101 & 4.16 \\
\hline Massachusetts. . & 4,052 & 99 & 2.44 \\
\hline Michigan ..... & 5,422 & 223 & 4.11 \\
\hline Minnesota & 2,859 & 74 & 2.59 \\
\hline Mississippi. . & 1,894 & 62 & 3.27 \\
\hline Missouri........ . & 3,950 & 175 & 4.43 \\
\hline Montana. ......... & 657 & 23 & 3.50 \\
\hline Nebraska . & 851 & 41 & 4.82 \\
\hline Nevada....... & 1,437 & 33 & 2.30 \\
\hline 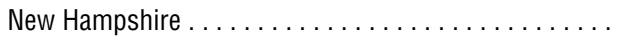 & 864 & 25 & 2.89 \\
\hline New Jersey & 4,650 & 279 & 6.00 \\
\hline New Mexico . . & 1,687 & 27 & 1.60 \\
\hline New York.... & 7,390 & 270 & 3.65 \\
\hline North Carolina . & 6,190 & 234 & 3.78 \\
\hline North Dakota . & 371 & 26 & 7.01 \\
\hline Ohio ............ & 8,287 & 287 & 3.46 \\
\hline Oklahoma $\ldots \ldots \ldots \ldots \ldots \ldots \ldots \ldots \ldots \ldots$ & 2,439 & 82 & 3.36 \\
\hline$\ldots \ldots \ldots \ldots$ & 2,213 & 39 & 1.76 \\
\hline Pennsylvania . & 8,596 & 312 & 3.63 \\
\hline Rhode Island $\ldots \ldots \ldots \ldots \ldots \ldots \ldots \ldots$ & 670 & 27 & 4.03 \\
\hline South Carolina . & 3,336 & 168 & 5.04 \\
\hline South Dakota . & 517 & 4 & 0.77 \\
\hline Tennessee ... & 4,856 & 234 & 4.82 \\
\hline Texas ..... & 11,384 & 602 & 5.29 \\
\hline Utah..... & 1,301 & 38 & 2.92 \\
\hline Vermont...... & 405 & 7 & 1.73 \\
\hline 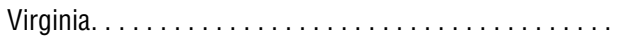 & 3,994 & 126 & 3.15 \\
\hline Washington $\ldots \ldots \ldots \ldots \ldots \ldots \ldots \ldots \ldots$ & 3,569 & 111 & 3.11 \\
\hline West Virginia $\ldots \ldots \ldots \ldots \ldots \ldots \ldots \ldots \ldots \ldots$ & 1,859 & 33 & 1.78 \\
\hline 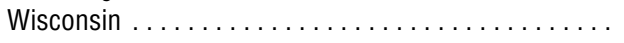 & 4,087 & 66 & 1.61 \\
\hline Wyoming $\ldots \ldots \ldots \ldots \ldots \ldots \ldots \ldots \ldots \ldots \ldots \ldots \ldots \ldots \ldots$ & 384 & 19 & 4.95 \\
\hline United States. & 173,040 & 6,369 & 3.68 \\
\hline
\end{tabular}

NOTES: Deaths from unintentional injury are identified using International Classification of Diseases, 10th Revision codes V01-X59 and Y85-Y86. X59, Exposure to unspecified factor causing other or unspecified injury, is a nonspecific mechanism code. A high value for the percentage of unintentional injury deaths with X59 indicates that a higher percentage of deaths lack sufficient information to assign a more specific injury mechanism code.

SOURCE: National Vital Statistics System, Mortality (NVSS-M), 2019. 
Table 2. Percentage of homicide deaths with Y09, Assault by unspecified means, as the underlying cause of death, by state: 2019

\begin{tabular}{|c|c|c|c|}
\hline Area & $\begin{array}{l}\text { All homicide } \\
\text { deaths }\end{array}$ & $\begin{array}{l}\text { Homicide deaths with Y09 } \\
\text { as the underlying cause }\end{array}$ & $\begin{array}{l}\text { Percent of homicide deaths with } \\
\text { Y09 as the underlying cause }\end{array}$ \\
\hline Alabama. & 587 & 31 & 5.28 \\
\hline Alaska & 78 & 5 & 6.41 \\
\hline Arizona. . & 414 & 51 & 12.32 \\
\hline Arkansas ............ & 270 & 15 & 5.56 \\
\hline California $\ldots \ldots \ldots \ldots \ldots \ldots \ldots \ldots \ldots \ldots$ & 1,794 & 108 & 6.02 \\
\hline Colorado $\ldots \ldots \ldots \ldots \ldots \ldots \ldots \ldots \ldots$ & 250 & 12 & 4.80 \\
\hline Connecticut $\ldots \ldots \ldots \ldots \ldots \ldots \ldots \ldots \ldots$ & 106 & 17 & 16.04 \\
\hline Delaware $\ldots \ldots \ldots \ldots \ldots \ldots \ldots \ldots \ldots \ldots \ldots$ & 53 & 3 & 5.66 \\
\hline District of Columbia $\ldots \ldots \ldots \ldots \ldots \ldots \ldots \ldots \ldots$ & 162 & 8 & 4.94 \\
\hline Florida $\ldots \ldots \ldots \ldots \ldots \ldots$ & 1,334 & 75 & 5.62 \\
\hline Georgia & 849 & 45 & 5.30 \\
\hline Hawaii $\ldots \ldots \ldots \ldots \ldots \ldots \ldots \ldots \ldots \ldots \ldots \ldots$ & 35 & 6 & 17.14 \\
\hline$\ldots \ldots \ldots \ldots \ldots \ldots \ldots \ldots$ & 27 & 2 & 7.41 \\
\hline$\ldots \ldots \ldots \ldots \ldots \ldots$ & 979 & 46 & 4.70 \\
\hline Indiana $\ldots \ldots \ldots \ldots \ldots \ldots \ldots \ldots \ldots \ldots \ldots$ & 466 & 37 & 7.94 \\
\hline lowa $\ldots \ldots \ldots \ldots \ldots \ldots \ldots \ldots \ldots \ldots \ldots$ & 80 & 14 & 17.50 \\
\hline 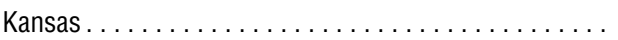 & 137 & 10 & 7.30 \\
\hline Kentucky $\ldots \ldots \ldots \ldots \ldots \ldots \ldots \ldots \ldots \ldots \ldots \ldots \ldots \ldots \ldots \ldots$ & 250 & 6 & 2.40 \\
\hline Louisiana $\ldots \ldots \ldots \ldots \ldots \ldots \ldots \ldots \ldots \ldots$ & 650 & 34 & 5.23 \\
\hline Maine.$\ldots \ldots \ldots \ldots \ldots \ldots \ldots \ldots \ldots \ldots \ldots \ldots \ldots \ldots \ldots \ldots$ & 23 & 13 & 56.52 \\
\hline Maryland ........... & 578 & 49 & 8.48 \\
\hline Massachusetts $\ldots \ldots \ldots \ldots \ldots \ldots \ldots \ldots \ldots$ & 157 & 13 & 8.28 \\
\hline Michigan $\ldots \ldots \ldots \ldots \ldots \ldots \ldots \ldots \ldots \ldots$ & 612 & 32 & 5.23 \\
\hline Minnesota $\ldots \ldots \ldots \ldots \ldots \ldots \ldots \ldots \ldots \ldots \ldots$ & 154 & 19 & 12.34 \\
\hline Mississippi. . . . . . . . . & 434 & 12 & 2.76 \\
\hline Missouri. ........................ & 628 & 17 & 2.71 \\
\hline Montana $\ldots \ldots \ldots \ldots \ldots \ldots \ldots \ldots \ldots \ldots \ldots$ & 39 & 5 & 12.82 \\
\hline Nebraska .................. & 58 & 4 & 6.90 \\
\hline Nevada............. & 166 & 18 & 10.84 \\
\hline New Hampshire ........ & 38 & 6 & 15.79 \\
\hline New Jersey $\ldots \ldots \ldots \ldots$ & 287 & 29 & 10.10 \\
\hline New Mexico $\ldots \ldots \ldots \ldots \ldots \ldots \ldots \ldots \ldots$ & 230 & 5 & 2.17 \\
\hline New York $\ldots \ldots \ldots \ldots \ldots \ldots \ldots \ldots \ldots \ldots \ldots \ldots \ldots$ & 601 & 80 & 13.31 \\
\hline North Carolina $\ldots \ldots \ldots \ldots \ldots \ldots \ldots \ldots \ldots$ & 707 & 41 & 5.80 \\
\hline North Dakota $\ldots \ldots \ldots \ldots \ldots \ldots \ldots \ldots \ldots \ldots$ & 21 & 1 & 4.76 \\
\hline Ohio $\ldots \ldots \ldots \ldots \ldots \ldots \ldots \ldots \ldots \ldots \ldots \ldots \ldots$ & 724 & 35 & 4.83 \\
\hline Oklahoma.......................... & 333 & 35 & 10.51 \\
\hline Oregon $\ldots \ldots \ldots \ldots \ldots \ldots \ldots \ldots \ldots \ldots \ldots$ & 126 & 13 & 10.32 \\
\hline Pennsylvania ......... . & 722 & 48 & 6.65 \\
\hline 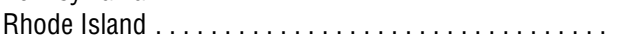 & 23 & 2 & 8.70 \\
\hline South Carolina .......................... & 527 & 19 & 3.61 \\
\hline South Dakota . . . . . . . . . . . . . . . . . . . & 29 & 3 & 10.34 \\
\hline Tennessee $\ldots \ldots \ldots \ldots \ldots \ldots \ldots \ldots \ldots \ldots$ & 596 & 33 & 5.54 \\
\hline Texas $\ldots \ldots \ldots \ldots \ldots \ldots \ldots \ldots \ldots \ldots \ldots$ & 1,694 & 126 & 7.44 \\
\hline$\ldots \ldots \ldots \ldots$ & 82 & 10 & 12.20 \\
\hline$\ldots \ldots \ldots \ldots$ & 11 & 3 & 27.27 \\
\hline Virginia........... & 436 & 20 & 4.59 \\
\hline Washington ......... & 241 & 27 & 11.20 \\
\hline West Virginia ......... & 92 & 4 & 4.35 \\
\hline Wisconsin .......... & 226 & 11 & 4.87 \\
\hline Wyoming $\ldots \ldots \ldots \ldots \ldots \ldots \ldots \ldots \ldots$ & 25 & 2 & 8.00 \\
\hline United States..... & 19,141 & 1,247 & 6.51 \\
\hline
\end{tabular}

NOTES: Homicide deaths are identified using International Classification of Diseases, 10th Revision codes U01-U02, X85-Y09, and Y87.1. Y09, Assault by unspecified means, is a nonspecific mechanism code. A high value for the percentage of homicides with Y09 indicates that a higher percentage of deaths lacked sufficient information to assign a more specific injury mechanism code.

SOURCE: National Vital Statistics System, Mortality (NVSS-M), 2019. 
Table 3. Percentage of unintentional fall deaths with W19, Unspecified fall, as the underlying cause of death, by state: 2019

\begin{tabular}{|c|c|c|c|}
\hline Area & $\begin{array}{l}\text { All unintentional } \\
\text { fall deaths }\end{array}$ & $\begin{array}{l}\text { Unintentional fall deaths with W19 as } \\
\text { the underlying cause }\end{array}$ & $\begin{array}{l}\text { Percent of unintentional } \\
\text { fall deaths with W19 as the } \\
\text { underlying cause }\end{array}$ \\
\hline Alabama. & 295 & 150 & 50.85 \\
\hline Alaska .. & 64 & 7 & 10.94 \\
\hline Arizona............ & 1,117 & 558 & 49.96 \\
\hline Arkansas ........... & 228 & 102 & 44.74 \\
\hline California ........... & 2,870 & 1,090 & 37.98 \\
\hline Colorado ...... & 884 & 438 & 49.55 \\
\hline Connecticut ......... & 441 & 346 & 78.46 \\
\hline Delaware ........... & 96 & 47 & 48.96 \\
\hline District of Columbia. . & 50 & 35 & 70.00 \\
\hline Florida $\ldots \ldots \ldots \ldots$ & 3,369 & 1,479 & 43.90 \\
\hline Georgia & 810 & 204 & 25.19 \\
\hline Hawaii ... & 167 & 101 & 60.48 \\
\hline Idaho...... & 269 & 44 & 16.36 \\
\hline$\ldots \ldots \ldots \ldots \ldots \ldots \ldots$ & 1,246 & 633 & 50.80 \\
\hline Indiana......... & 541 & 243 & 44.92 \\
\hline lowa...... & 519 & 146 & 28.13 \\
\hline Kansas..... & 428 & 239 & 55.84 \\
\hline Kentucky ...... & 420 & 191 & 45.48 \\
\hline Louisiana...... . & 326 & 167 & 51.23 \\
\hline Maine....... & 370 & 298 & 80.54 \\
\hline Maryland ........ & 766 & 505 & 65.93 \\
\hline Massachusetts.... & 1,001 & 792 & 79.12 \\
\hline Michigan $\ldots \ldots \ldots \ldots \ldots \ldots \ldots \ldots \ldots \ldots \ldots$ & 1,304 & 700 & 53.68 \\
\hline Minnesota $\ldots \ldots \ldots \ldots \ldots \ldots \ldots \ldots \ldots \ldots \ldots \ldots \ldots \ldots$ & 1,223 & 394 & 32.22 \\
\hline Mississippi. ...................... & 328 & 174 & 53.05 \\
\hline Missouri........ & 784 & 510 & 65.05 \\
\hline Montana. ...... & 194 & 73 & 37.63 \\
\hline Nebraska . & 243 & 100 & 41.15 \\
\hline Nevada... . & 331 & 153 & 46.22 \\
\hline New Hampshire. & 252 & 94 & 37.30 \\
\hline New Jersey & 604 & 369 & 61.09 \\
\hline New Mexico . . . & 400 & 30 & 7.50 \\
\hline New York...... & 1,751 & 941 & 53.74 \\
\hline$\ldots \ldots \ldots \ldots \ldots \ldots$ & 1,495 & 544 & 36.39 \\
\hline North Dakota ... . & 80 & 35 & 43.75 \\
\hline Ohio .......... & 1,704 & 674 & 39.55 \\
\hline Oklahoma.... & 707 & 673 & 95.19 \\
\hline Oregon..... & 774 & 81 & 10.47 \\
\hline Pennsylvania & 2,025 & 871 & 43.01 \\
\hline Rhode Island . & 196 & 157 & 80.10 \\
\hline South Carolina.. . & 611 & 314 & 51.39 \\
\hline$\ldots \ldots \ldots \ldots \ldots \ldots$ & 205 & 66 & 32.20 \\
\hline$\ldots \ldots \ldots \ldots \ldots \ldots$ & 831 & 434 & 52.23 \\
\hline$\ldots \ldots \ldots \ldots \ldots \ldots \ldots \ldots \ldots$ & 2,169 & 1,231 & 56.75 \\
\hline$\ldots \ldots \ldots \ldots \ldots \ldots \ldots \ldots \ldots$ & 345 & 46 & 13.33 \\
\hline$\ldots \ldots \ldots \ldots \ldots \ldots \ldots$ & 164 & 26 & 15.85 \\
\hline Virginia..... & 968 & 256 & 26.45 \\
\hline Washington . & 1,103 & 146 & 13.24 \\
\hline West Virginia . & 452 & 27 & 5.97 \\
\hline Wisconsin . & 1,823 & 608 & 33.35 \\
\hline Wyoming. & 100 & 34 & 34.00 \\
\hline United States . . & 39,443 & 17,576 & 44.56 \\
\hline
\end{tabular}

NOTES: Unintentional fall deaths are identified using International Classification of Diseases, 10th Revision codes W00-W19. W19, Unspecified fall, is a less specific mechanism code. A high value for the percentage of unintentional fall deaths with W19 indicates that a higher percentage of deaths lacked sufficient information to assign a more specific fall code.

SOURCE: National Vital Statistics System, Mortality (NVSS-M), 2019. 
Table 4. Percentage of unintentional motor vehicle traffic-related deaths with V89.2, Person injured in unspecified motor-vehicle accident, traffic, as the underlying cause of death, by state: 2019

\begin{tabular}{|c|c|c|c|}
\hline Area & $\begin{array}{l}\text { All unintentional } \\
\text { motor vehicle } \\
\text { traffic-related deaths }\end{array}$ & $\begin{array}{l}\text { Unintentional motor vehicle } \\
\text { traffic-related deaths } \\
\text { with V89.2 as the } \\
\text { underlying cause }\end{array}$ & $\begin{array}{l}\text { Percent of unintentional } \\
\text { motor vehicle traffic-related } \\
\text { deaths with V89.2 as the } \\
\text { underlying cause }\end{array}$ \\
\hline Alabama. . & 981 & 411 & 41.90 \\
\hline Alaska .. & 72 & 22 & 30.56 \\
\hline$\ldots \ldots \ldots \ldots$ & 945 & 401 & 42.43 \\
\hline (............ & 534 & 218 & 40.82 \\
\hline$\ldots \ldots \ldots \ldots$ & 3,885 & 889 & 22.88 \\
\hline Colorado & 614 & 211 & 34.36 \\
\hline Connecticut & 255 & 120 & 47.06 \\
\hline$\ldots \ldots \ldots \ldots \ldots \ldots \ldots \ldots$ & 131 & 39 & 29.77 \\
\hline District of Columbia $\ldots \ldots \ldots \ldots \ldots \ldots \ldots \ldots \ldots \ldots$ & 44 & 14 & 31.82 \\
\hline Florida $\ldots \ldots \ldots \ldots \ldots \ldots \ldots \ldots$ & 3,206 & 155 & 4.83 \\
\hline Georgia & 1,492 & 514 & 34.45 \\
\hline$\ldots \ldots \ldots$ & 118 & 28 & 23.73 \\
\hline Idaho . . & 241 & 17 & 7.05 \\
\hline$\ldots \ldots \ldots \ldots$ & 1,102 & 380 & 34.48 \\
\hline$\cdots \ldots \ldots \ldots$ & 839 & 340 & 40.52 \\
\hline$\ldots \ldots \ldots \ldots \ldots$ & 351 & 90 & 25.64 \\
\hline 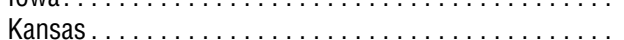 & 383 & 204 & 53.26 \\
\hline Kentucky $\ldots \ldots \ldots \ldots \ldots \ldots \ldots \ldots \ldots \ldots$ & 735 & 268 & 36.46 \\
\hline Louisiana . . $\ldots \ldots \ldots \ldots \ldots \ldots \ldots \ldots \ldots \ldots$ & 728 & 314 & 43.13 \\
\hline Maine........................... & 159 & 30 & 18.87 \\
\hline Maryland. & 537 & 158 & 29.42 \\
\hline Massachusetts. . & 378 & 202 & 53.44 \\
\hline$\ldots \ldots \ldots \ldots \ldots$ & 1,017 & 380 & 37.36 \\
\hline Minnesota $\ldots \ldots \ldots \ldots \ldots \ldots \ldots \ldots \ldots \ldots$ & 421 & 105 & 24.94 \\
\hline Mississippi. $\ldots \ldots \ldots \ldots \ldots \ldots \ldots \ldots \ldots \ldots \ldots \ldots$ & 724 & 223 & 30.80 \\
\hline 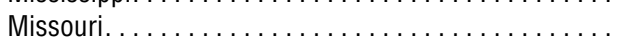 & 926 & 331 & 35.75 \\
\hline Montana $\ldots \ldots \ldots \ldots \ldots \ldots \ldots \ldots \ldots \ldots \ldots$ & 174 & 77 & 44.25 \\
\hline 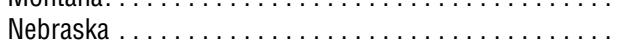 & 253 & 87 & 34.39 \\
\hline 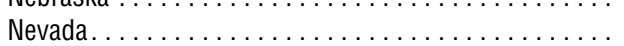 & 294 & 105 & 35.71 \\
\hline New Hampshire $\ldots \ldots \ldots \ldots \ldots \ldots \ldots \ldots \ldots$ & 103 & 25 & 24.27 \\
\hline New Jersey $\ldots \ldots \ldots \ldots \ldots \ldots \ldots \ldots$ & 584 & 167 & 28.60 \\
\hline$\ldots \ldots \ldots \ldots$ & 394 & 81 & 20.56 \\
\hline New York $\ldots \ldots \ldots \ldots \ldots \ldots \ldots \ldots \ldots \ldots$ & 1,072 & 255 & 23.79 \\
\hline North Carolina $\ldots \ldots \ldots \ldots \ldots \ldots \ldots \ldots \ldots \ldots$ & 1,561 & 648 & 41.51 \\
\hline North Dakota $\ldots \ldots \ldots \ldots \ldots \ldots \ldots \ldots \ldots \ldots \ldots$ & 97 & 42 & 43.30 \\
\hline Ohio & 1,219 & 400 & 32.81 \\
\hline Oklahoma $\ldots \ldots \ldots \ldots \ldots \ldots \ldots \ldots \ldots \ldots \ldots \ldots \ldots$ & 669 & 295 & 44.10 \\
\hline 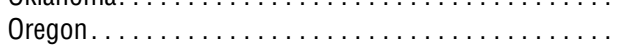 & 506 & 54 & 10.67 \\
\hline 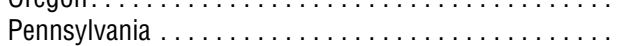 & 1,079 & 433 & 40.13 \\
\hline Rhode Island $\ldots \ldots \ldots \ldots \ldots \ldots \ldots \ldots \ldots$ & 71 & 29 & 40.85 \\
\hline South Carolina . & 983 & 428 & 43.54 \\
\hline South Dakota. . & 129 & 14 & 10.85 \\
\hline Tennessee $\ldots \ldots \ldots \ldots \ldots \ldots \ldots \ldots \ldots \ldots$ & 1,138 & 611 & 53.69 \\
\hline Texas & 3,727 & 1,108 & 29.73 \\
\hline 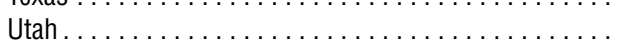 & 231 & 90 & 38.96 \\
\hline 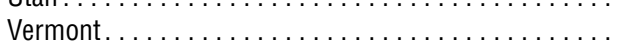 & 51 & 9 & 17.65 \\
\hline Virginia & 870 & 372 & 42.76 \\
\hline 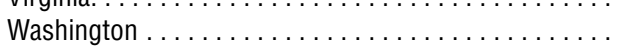 & 604 & 117 & 19.37 \\
\hline 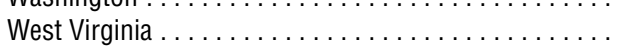 & 296 & 103 & 34.80 \\
\hline 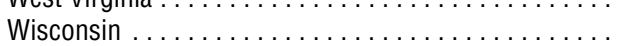 & 567 & 49 & 8.64 \\
\hline 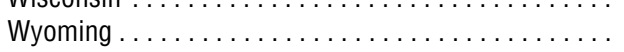 & 105 & 41 & 39.05 \\
\hline United States $\ldots \ldots \ldots \ldots \ldots \ldots \ldots \ldots \ldots \ldots$ & 37,595 & 11,704 & 31.13 \\
\hline
\end{tabular}

NOTES: Unintentional motor vehicle traffic-related deaths are identified using International Classification of Diseases, 10th Revision codes V02-V04 (.1,.9), V09.2, V12-V14 (.3-.9), V19 (.4-.6), V20-V28 (.3-.9), V29-V79 (.4-.9), V80 (.3-.5), V81.1, V82.1, V83-V86 (.0-.3), V87 (.0-.8), and V89.2. V89.2, Person injured in unspecified motor-vehicle accident, traffic, is a less specific mechanism code. A high value for the percentage of unintentional motor vehicle traffic-related deaths with V89.2 indicates that a higher percentage of deaths lacked sufficient information to assign a more specific motor vehicle traffic-related code.

SOURCE: National Vital Statistics System, Mortality (NVSS-M), 2019. 
Table 5. Percentage of firearm-related suicide and intentional self-harm deaths with $\mathrm{X74}$, Intentional self-harm by other and unspecified firearm discharge, as the underlying cause of death, by state: 2019

\begin{tabular}{|c|c|c|c|}
\hline Area & $\begin{array}{l}\text { All firearm-related } \\
\text { suicide and intentional } \\
\text { self-harm deaths }\end{array}$ & $\begin{array}{c}\text { Firearm-related suicide } \\
\text { and intentional self-harm } \\
\text { deaths with X74 as the } \\
\text { underlying cause }\end{array}$ & $\begin{array}{c}\text { Percent of firearm-related } \\
\text { suicide and intentional self-harm } \\
\text { deaths with } X 74 \text { as } \\
\text { the underlying cause }\end{array}$ \\
\hline$\ldots \ldots \ldots$ & 543 & 400 & 73.66 \\
\hline$\ldots \ldots \ldots \ldots$ & 117 & 83 & 70.94 \\
\hline .............. & 809 & 582 & 71.94 \\
\hline Arkansas $\ldots \ldots \ldots \ldots \ldots \ldots \ldots \ldots$ & 341 & 283 & 82.99 \\
\hline California . . . . . . . . . . . . & 1,586 & 511 & 32.22 \\
\hline$\ldots \ldots \ldots \ldots$ & 647 & 380 & 58.73 \\
\hline Connecticut & 118 & 97 & 82.20 \\
\hline$\ldots \ldots \ldots \ldots$ & 45 & 37 & 82.22 \\
\hline District of Columbia ............. & 12 & 12 & 100.00 \\
\hline Florida ................... & 1,808 & 1,197 & 66.21 \\
\hline Georgia & 955 & 675 & 70.68 \\
\hline (n......... & 41 & 39 & 95.12 \\
\hline$\ldots \ldots \ldots$ & 223 & 6 & 2.69 \\
\hline$\ldots \ldots \ldots \ldots$ & 540 & 449 & 83.15 \\
\hline$\ldots \ldots \ldots \ldots$ & 570 & 442 & 77.54 \\
\hline$\ldots \ldots \ldots \ldots$ & 233 & 68 & 29.18 \\
\hline$\ldots \ldots \ldots \ldots \ldots \ldots \ldots \ldots \ldots \ldots$ & 291 & 226 & 77.66 \\
\hline Kentucky .......................... & 445 & 368 & 82.70 \\
\hline Louisiana $\ldots \ldots \ldots \ldots \ldots \ldots \ldots \ldots \ldots \ldots \ldots$ & 446 & 396 & 88.79 \\
\hline Maine $\ldots \ldots \ldots \ldots \ldots \ldots \ldots \ldots \ldots$ & 144 & 6 & 4.17 \\
\hline Maryland . & 268 & 203 & 75.75 \\
\hline Massachusetts.............. & 142 & 116 & 81.69 \\
\hline Michigan $\ldots \ldots \ldots \ldots \ldots \ldots$ & 742 & 485 & 65.36 \\
\hline 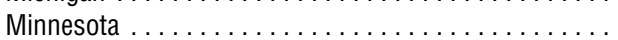 & 350 & 200 & 57.14 \\
\hline Mississippi. $\ldots \ldots \ldots \ldots \ldots \ldots \ldots \ldots \ldots \ldots \ldots$ & 308 & 253 & 82.14 \\
\hline Missouri. $\ldots \ldots \ldots \ldots \ldots \ldots \ldots \ldots \ldots \ldots \ldots$ & 681 & 396 & 58.15 \\
\hline Montana. .......................... & 172 & 115 & 66.86 \\
\hline Nebraska ............................ & 154 & 122 & 79.22 \\
\hline 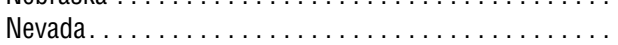 & 354 & 231 & 65.25 \\
\hline New Hampshire ....................... & 132 & 76 & 57.58 \\
\hline New Jersey $\ldots \ldots \ldots \ldots \ldots \ldots$ & 173 & 145 & 83.82 \\
\hline New Mexico ................ & 284 & 227 & 79.93 \\
\hline New York $\ldots \ldots \ldots \ldots \ldots \ldots \ldots \ldots \ldots \ldots$ & 455 & 339 & 74.51 \\
\hline North Carolina $\ldots \ldots \ldots \ldots \ldots \ldots \ldots \ldots \ldots$ & 781 & 443 & 56.72 \\
\hline North Dakota . . . . . . . . . . . . . . . . . . . & 79 & 37 & 46.84 \\
\hline Ohio & 980 & 805 & 82.14 \\
\hline 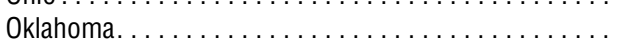 & 473 & 52 & 10.99 \\
\hline Oregon & 466 & 35 & 7.51 \\
\hline Pennsylvania $\ldots \ldots \ldots \ldots \ldots \ldots \ldots \ldots \ldots \ldots \ldots \ldots$ & 964 & 785 & 81.43 \\
\hline Rhode Island $\ldots \ldots \ldots \ldots \ldots \ldots \ldots \ldots \ldots$ & 33 & 27 & 81.82 \\
\hline South Carolina ............... & 532 & 489 & 91.92 \\
\hline South Dakota . . . . . . . . . . . . . & 98 & 6 & 6.12 \\
\hline Tennessee $\ldots \ldots \ldots \ldots \ldots \ldots \ldots \ldots \ldots \ldots$ & 746 & 608 & 81.50 \\
\hline Texas & 2,237 & 1,838 & 82.16 \\
\hline $\mathrm{Utah}$ & 329 & 134 & 40.73 \\
\hline Vermont & 59 & 3 & 5.08 \\
\hline Virginia. & 661 & 322 & 48.71 \\
\hline Washington $\ldots \ldots \ldots \ldots \ldots \ldots \ldots \ldots \ldots \ldots \ldots$ & 637 & 123 & 19.31 \\
\hline 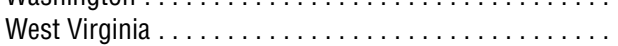 & 196 & 112 & 57.14 \\
\hline 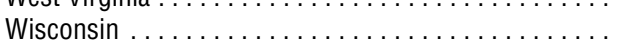 & 427 & 23 & 5.39 \\
\hline Wyoming & 114 & 53 & 46.49 \\
\hline United States . . . . . . . . . . . . . . . . . . . . & 23,941 & 15,060 & 62.90 \\
\hline
\end{tabular}

NOTES: Firearm-related suicide and intentional self-harm deaths are identified using International Classification of Diseases, 10th Revision codes X72-X74. X74, Intentional self-harm by other and unspecified firearm discharge, is a less specific mechanism code. A high value for the percentage of firearm-related suicide and intentional self-harm deaths with X74 indicates that a higher percentage of deaths lacked sufficient information to assign a more specific firearm code.

SOURCE: National Vital Statistics System, Mortality (NVSS-M), 2019. 
Table 6. Percentage of firearm-related homicides with X95, Assault by other and unspecified firearm discharge, as the underlying cause of death, by state: 2019

\begin{tabular}{|c|c|c|c|}
\hline Area & $\begin{array}{c}\text { All firearm-related } \\
\text { homicides }\end{array}$ & $\begin{array}{c}\text { Firearm-related homicides } \\
\text { with X95 as the } \\
\text { underlying cause }\end{array}$ & $\begin{array}{c}\text { Percent of firearm-related } \\
\text { homicides with X95 as the } \\
\text { underlying cause }\end{array}$ \\
\hline Alabama. . & 486 & 373 & 76.75 \\
\hline Alaska ... & 51 & 46 & 90.20 \\
\hline Arizona. . & 285 & 272 & 95.44 \\
\hline Arkansas & 208 & 195 & 93.75 \\
\hline California . & 1,246 & 1,011 & 81.14 \\
\hline Colorado & 164 & 140 & 85.37 \\
\hline Connecticut & 65 & 64 & 98.46 \\
\hline Delaware .. & 45 & 45 & 100.00 \\
\hline District of Columbia ... & 128 & 125 & 97.66 \\
\hline Florida $\ldots \ldots \ldots \ldots \ldots$ & 1,013 & 841 & 83.02 \\
\hline Georgia . & 691 & 665 & 96.24 \\
\hline Hawaii ... & 14 & 14 & 100.00 \\
\hline Idaho . . & 18 & 3 & 16.67 \\
\hline Illinois & 791 & 772 & 97.60 \\
\hline Indiana. . & 355 & 334 & 94.08 \\
\hline Iowa.... & 49 & 41 & 83.67 \\
\hline Kansas . . & 99 & 95 & 95.96 \\
\hline Kentucky . & 201 & 189 & 94.03 \\
\hline Louisiana ......... & 542 & 527 & 97.23 \\
\hline$\ldots \ldots \ldots \ldots \ldots \ldots \ldots$ & 13 & 5 & 38.46 \\
\hline Maryland ....... & 468 & 463 & 98.93 \\
\hline Massachusetts... & 95 & 94 & 98.95 \\
\hline Michigan ........ & 458 & 444 & 96.94 \\
\hline Minnesota & 102 & 89 & 87.25 \\
\hline Mississippi. . & 366 & 345 & 94.26 \\
\hline Missouri. . . . . . . . . . & 537 & 516 & 96.09 \\
\hline Montana. .......... & 24 & 23 & 95.83 \\
\hline Nebraska ....... . & 40 & 35 & 87.50 \\
\hline Nevada.......... & 118 & 110 & 93.22 \\
\hline New Hampshire $\ldots \ldots \ldots \ldots \ldots \ldots \ldots \ldots \ldots$ & 20 & 19 & 95.00 \\
\hline New Jersey & 193 & 189 & 97.93 \\
\hline New Mexico.... & 158 & 137 & 86.71 \\
\hline New York ......... & 326 & 315 & 96.63 \\
\hline North Carolina .... . & 541 & 467 & 86.32 \\
\hline North Dakota .... . & 10 & 5 & 50.00 \\
\hline Ohio ............. & 565 & 550 & 97.35 \\
\hline 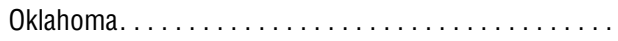 & 246 & 133 & 54.07 \\
\hline Oregon............ & 78 & 43 & 55.13 \\
\hline Pennsylvania .... . & 548 & 533 & 97.26 \\
\hline Rhode Island $\ldots \ldots \ldots \ldots \ldots \ldots \ldots \ldots \ldots \ldots$ & 12 & 12 & 100.00 \\
\hline South Carolina. . & 453 & 439 & 96.91 \\
\hline South Dakota... & 11 & 3 & 27.27 \\
\hline Tennessee .... & 474 & 459 & 96.84 \\
\hline Texas .......... & 1,299 & 1,185 & 91.22 \\
\hline Utah..... & 51 & 44 & 86.27 \\
\hline Vermont......... & 5 & 4 & 80.00 \\
\hline Virginia. ............................. & 342 & 222 & 64.91 \\
\hline Washington $\ldots \ldots \ldots \ldots \ldots \ldots \ldots \ldots \ldots \ldots \ldots$ & 165 & 139 & 84.24 \\
\hline West Virginia $\ldots \ldots \ldots \ldots \ldots \ldots \ldots \ldots \ldots \ldots$ & 76 & 45 & 59.21 \\
\hline Wisconsin $\ldots \ldots \ldots \ldots \ldots \ldots \ldots \ldots \ldots \ldots \ldots \ldots \ldots \ldots \ldots$ & 153 & 74 & 48.37 \\
\hline Wyoming $\ldots \ldots \ldots \ldots \ldots \ldots \ldots \ldots \ldots \ldots \ldots \ldots \ldots \ldots \ldots$ & 16 & 13 & 81.25 \\
\hline United States . . & 14,414 & 12,906 & 89.53 \\
\hline
\end{tabular}

NOTES: Firearm-related homicides are identified using International Classification of Diseases, 10th Revision codes X93-X95. X95, Assault by other and unspecified firearm discharge, is a less specific mechanism code. A high value for the percentage of firearm-related homicides with X95 indicates that a higher percentage of deaths lacked sufficient information to assign a more specific firearm code.

SOURCE: National Vital Statistics System, Mortality (NVSS-M), 2019. 


\section{Technical Notes}

The Table provides a list of the International Classification of Diseases, 10th Revision underlying cause-of-death codes for the intent-by-mechanism-of-injury categories included in Table B.

\section{Table. International Classification of Diseases, 10th Revision underlying cause codes for selected intent and mechanism of} injury groups

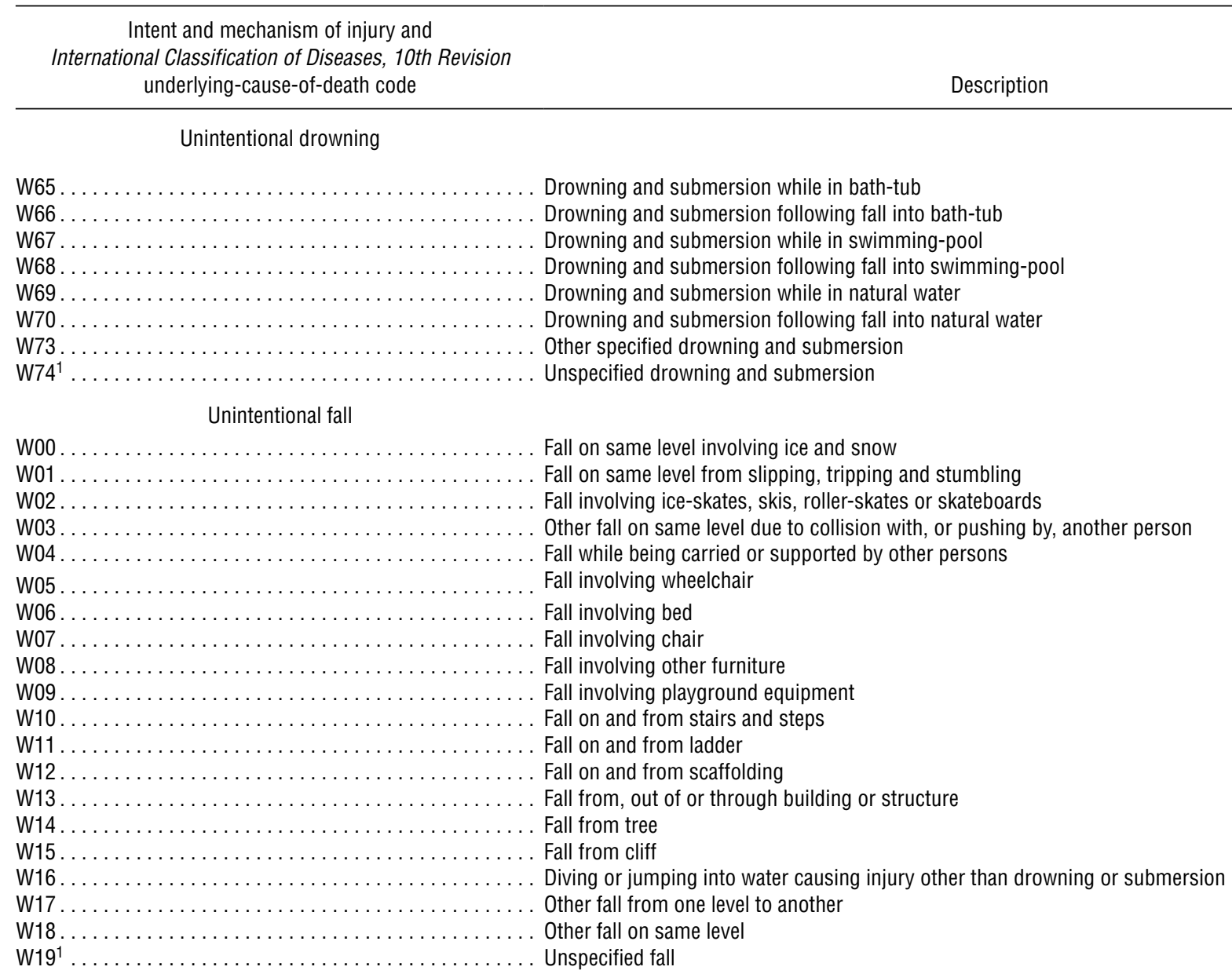

Unintentional fire or flames

\begin{tabular}{|c|c|}
\hline $\mathrm{X} 00$ & Exposure to uncontrolled fire in building or structure \\
\hline $\mathrm{X} 01$ & Exposure to uncontrolled fire, not in building or structure \\
\hline $\mathrm{X} 02$ & Exposure to controlled fire in building or structure \\
\hline $\mathrm{X} 03$ & Exposure to controlled fire, not in building or structure \\
\hline $\mathrm{X} 04$ & Exposure to ignition of highly flammable material \\
\hline X05 & Exposure to ignition or melting of nightwear \\
\hline $\mathrm{X} 06$ & Exposure to ignition or melting of other clothing and apparel \\
\hline $\mathrm{X} 08$ & Exposure to other specified smoke, fire and flames \\
\hline $\mathrm{X} 09^{1}$ & Exposure to unspecified smoke, fire and flames \\
\hline \multicolumn{2}{|c|}{ Unintentional hot object or substance } \\
\hline $\mathrm{X} 10$ & Contact with hot drinks, food, fats and cooking oils \\
\hline $\mathrm{X} 11$ & Contact with hot tap-water \\
\hline $\mathrm{X} 12$ & Contact with other hot fluids \\
\hline $\mathrm{X} 13$ & Contact with steam and hot vapours \\
\hline $\mathrm{X} 14$ & Contact with hot air and gases \\
\hline $\mathrm{X} 15$ & Contact with hot household appliances \\
\hline $\mathrm{X} 16$ & Contact with hot heating appliances, radiators and pipes \\
\hline $\mathrm{X} 17$ & Contact with hot engines, machinery and tools \\
\hline $\mathrm{X} 18$ & Contact with other hot metals \\
\hline $\mathrm{X} 19^{1}$ & Contact with other and unspecified heat and hot substances \\
\hline
\end{tabular}


Table. International Classification of Diseases, 10th Revision underlying cause codes for selected intent and mechanism of injury groups-Con.

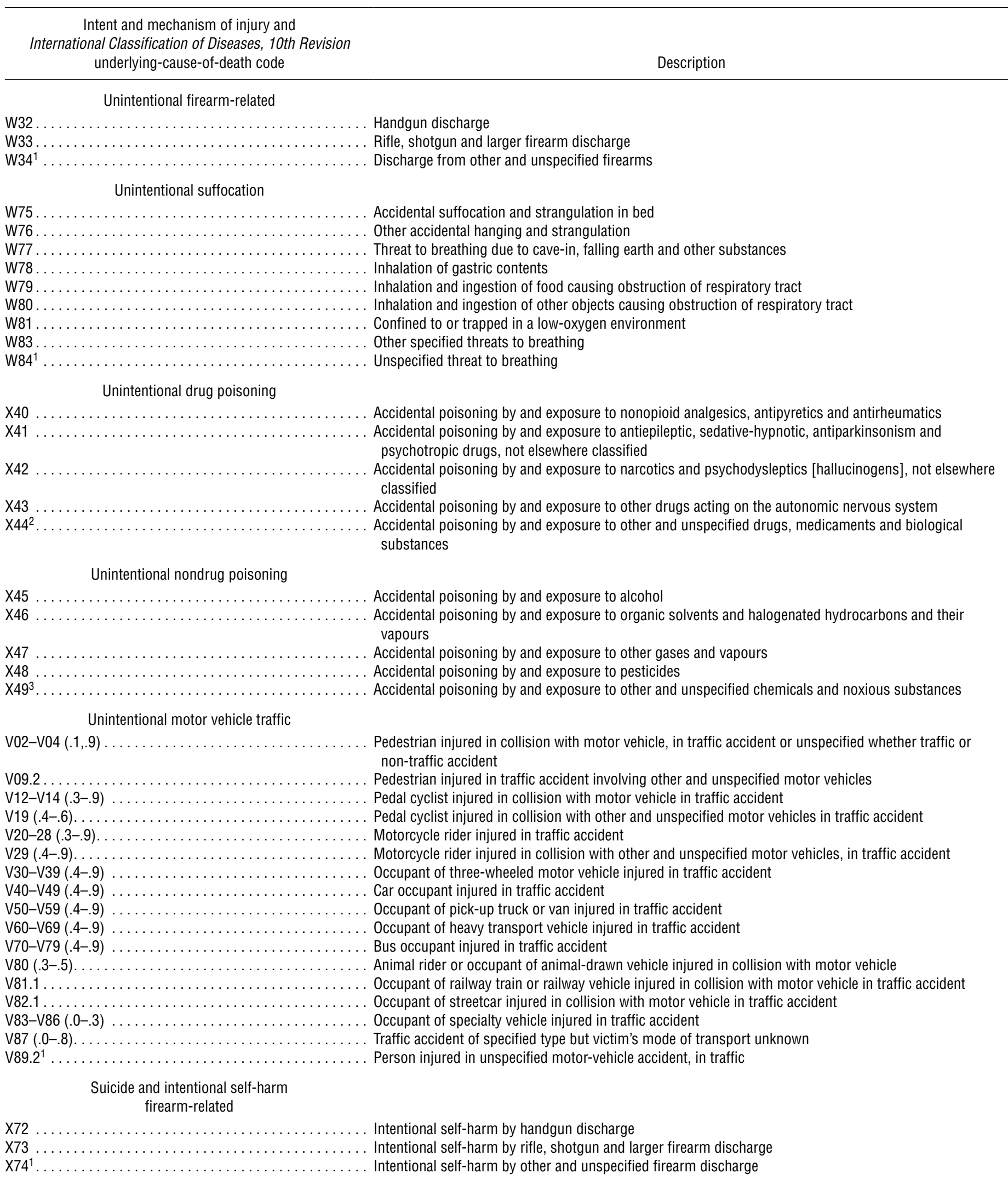


Table. International Classification of Diseases, 10th Revision underlying cause codes for selected intent and mechanism of injury groups-Con.

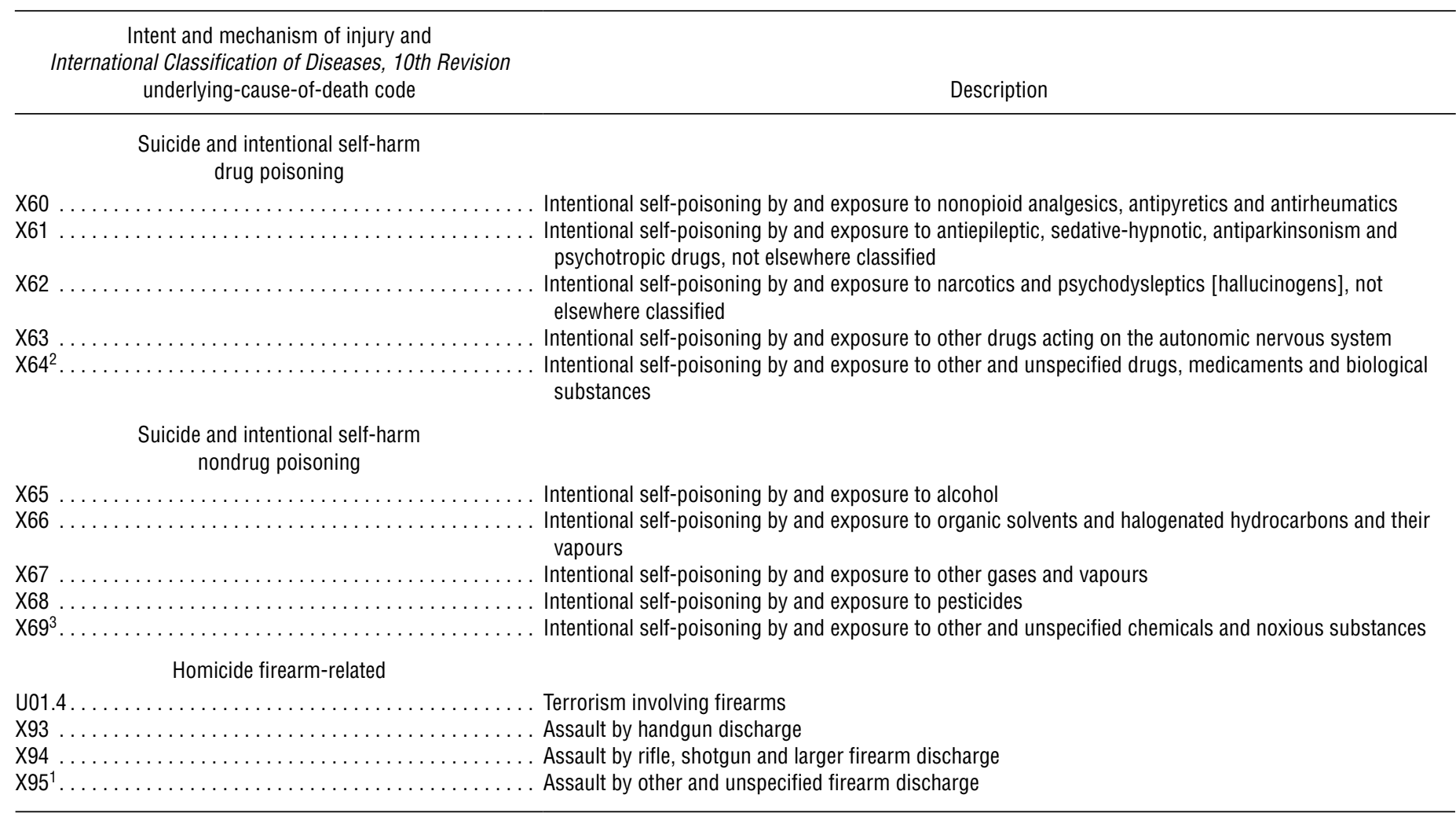

${ }^{1}$ Nonspecific-injury-mechanism code.

${ }^{2}$ Nonspecific-injury-mechanism code, when the only associated drug-related multiple cause code is T50.9, Other and unspecified drugs, medicaments and biological substances.

${ }^{3}$ Nonspecific-injury-mechanism code, when the only associated nondrug-related multiple cause code is T65.9, Toxic effect of unspecified substance.

NOTE: Code groupings are based on the International Classification of Diseases, 10th Revision External Cause of Injury Mortality Matrix, available from: https://www.cdc.gov/nchs/injury/

injury_tools.htm.

SOURCE: National Center for Health Statistics, 2021. 


\section{U.S. DEPARTMENT OF \\ HEALTH \& HUMAN SERVICES}

FIRST CLASS MAIL

POSTAGE \& FEES PAID

$\mathrm{CDC} / \mathrm{NCHS}$

Centers for Disease Control and Prevention

PERMIT NO. G-284

National Center for Health Statistics

3311 Toledo Road, Room 4551, MS P08

Hyattsville, MD 20782-2064

OFFICIAL BUSINESS

PENALTY FOR PRIVATE USE, $\$ 300$

For more NCHS NVSRs, visit:

https://www.cdc.gov/nchs/products/nvsr.htm.

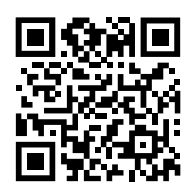

National Vital Statistics Reports, Vol. 70, No. 13, December 7, 2021

\section{Contents}

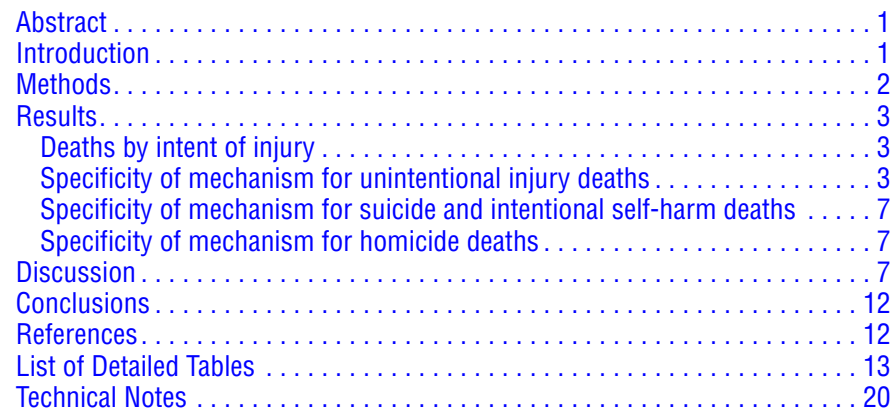

\section{Suggested citation}

Hedegaard $\mathrm{H}$, Warner M. Evaluating the cause-of-death information needed for estimating the burden of injury mortality: United States, 2019. National Vital Statistics Reports; vol 70 no 13. Hyattsville, MD: National Center for Health Statistics. 2021. DOI: https:// dx.doi.org/10.15620/cdc:110638.

\section{Copyright information}

All material appearing in this report is in the public domain and may be reproduced or copied without permission; citation as to source, however, is appreciated.
National Center for Health Statistics

Brian C. Moyer, Ph.D., Director

Amy M. Branum, Ph.D., Associate Director for Science

Division of Analysis and Epidemiology

Irma E. Arispe, Ph.D., Director

Kevin C. Heslin, Ph.D., Associate Director for Science

Division of Vital Statistics

Steven Schwartz, Ph.D., Director

Isabelle Horon, Dr.P.H., Acting Associate Director for Science

For e-mail updates on NCHS publication releases, subscribe online at: https://www.cdc.gov/nchs/email-updates.htm. For questions or general information about NCHS: Tel: 1-800-CDC-INFO (1-800-232-4636) • TTY: 1-888-232-6348 Internet: https://www.cdc.gov/nchs • Online request form: https://www.cdc.gov/info • CS327257 